\title{
الصلابة النفسية وعلاقتها بالاستجابات التكيفية للضغوط النفسية لاى الطلبة الموهوبين بالصف الحادي عشر في دولة الكويت
}

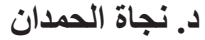

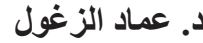 \\ د. بشائر علي الطبيخ
}

\section{Psychological Hardiness and its \\ Relationship to Coping Responses to \\ Psychological Stresses among Eleventh Grade Gifted Students in Kuwait}

Abstarct: This study aimed at identifying the level of psychological hardiness among the gifted students in the eleventh grade in the State of Kuwait and identifying their coping responses to psychological stresses, as well as determining the relation between the psychological hardiness and coping responses to psychological stresses. The study sample consisted of (112) gifted students (46 male and 66 female) from all districts of Al-Kuwait. The study used the descriptive approach. The study used the academic achievement records, Raven's Progressive Matrices prepared by AbdulRauf (1999), and Torrance Test of Creative Thinking (B) For the identification of gifted students. The Psychological Hardiness Scale (Mukhaimar, 2012) and Moos Coping Inventory (Moos, 2004) were used as study data collection. The results showed that the level of psychological hardiness among the gifted students was high (\%79.37) and above hypothetical mean. The highest level of psychological hardiness was in "commitment", "challenge" and "control" respectively. The results showed that the highest coping responses to psychological stresses among the sample were positive adaptive responses namely: logical analysis, problem solving, and the positive evaluation. The results also showed a statistically significant positive correlation coefficient $(0.05)$ between psychological hardness and the following dimensions of the coping responses: logical analysis, positive evaluation, seeking support and guidance, as well as problem solving. The results indicated that there are statistically significant differences in the level of psychological hardiness and the grades of commitment and challenge among the gifted students attributed to gender in favor of females but not for control, and there are statistically significant differences in the dimensions of the coping responses (positive evaluation, seeking support and guidance and emotional catharsis) attributed to gender in favor of females, while there are no statistically significant differences in the dimensions of coping responses including logical analysis, problem solving, cognitive avoidance, surrender and withdrawal and looking for alternative solutions among the gifted students attributed to gender.

Keywords: giftedness, psychological hardness, coping responses, psychological stresses, Kuwait.

$$
\begin{aligned}
& \text { الملخـص: هدفت الدر اســة إلى معرفـة مسـتوى الصلابــة النفسية لـدى } \\
& \text { طلبــة الصـف الحـادي عثـر المو هوبيـن فـي دولـة الكويــ، ومعرفــة } \\
& \text { الاسـتجابات التكيفيـة للضغــوط النفسـية لديهـم، ومعرفـة طبيعـة العلاقـة } \\
& \text { بيـن الصلابــة النفسـية و الاسـتجابات التكيفيـة للضغنـوط النفسـية. تكونــت } \\
& \text { عينـة الدر اسـة مـن (112) مـن طلبـة الصـف الحـادي عثـر المو هوبيـن }
\end{aligned}
$$

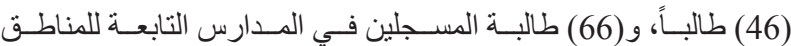

$$
\begin{aligned}
& \text { التعليميـة السـت بدولـة الكويت. اتبعت الدر اسـة المنهـج الوصفي. اشـتملت } \\
& \text { أدو ات الدر اسـة على ســلات التحصيـل الأكاديمس، و اختبـار المصفوفـات } \\
& \text { المتتابعـة لر افن إعـداد عبدالـرؤوف (1999)، واختبـار تور انس للتفكير } \\
& \text { الإبداعـي الصــورة (B) أدوات لفـرز الطلبـة المو هوبيـن، وتـم إسـتخدام } \\
& \text { مقيـاس الصلابـة النفسية (مخيمـر، 2012)، وقائمـة الاستجابات التكيفيـة } \\
& \text { للضغــوط النفسـية (Moos, 2004) كأدو ات لجمـع بيانـات الدراسـة. } \\
& \text { أظهرت النتائج أن مسـتوى الصـلابـة النفسية لـدى المو هو بيـن كان مرتفعـاً } \\
& \text { و أعلى مـن الوسـط الفرضـي حيث بلـغ (79.37\%)، وأن أعلى مسـتوى }
\end{aligned}
$$

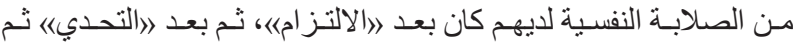

$$
\begin{aligned}
& \text { بعد 》التحكم)《، وأظهرت النتائُج أن أعلى الاستجابات التكيفيـة للضغوط } \\
& \text { النفسية لـدى عينـة الطلبـة المو هو بيـن كانـت مـن نـوع الاستجابات التكيفية } \\
& \text { الإيجابيـة، وكانـت علـى التو الـي: التـليـل المنطقي، حـل المشـكلة، ثـم } \\
& \text { التقييـم الإيجابـي، كمـا أظهـرت النتائهج وجـود علاقـة ارتباطيـة موجبـة } \\
& \text { دالـة إحصائيـاً (0.05) بيـن الصلابـة النفسـية وبيـن أبعـاد مقيـاس } \\
& \text { الاسـتجابات التكيفيـة التاليـة: التحليـل المنطقي، التقييم الأيجابـي، البحـث } \\
& \text { عن الدعم و التوجيـه، حل المشكلة. توصلت النتائج إلى وجـود فروق } \\
& \text { دالـة إحصائيـا في مستوى الصلابـة النفسية وفي درجـات أبعـاد الالتز ام } \\
& \text { و التحـدي للدى المو هوبيـن تعزى للنوع ع الاجتماعي لصالـح الإنـاث، في }
\end{aligned}
$$

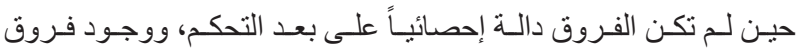

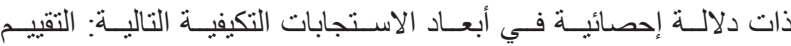

$$
\begin{aligned}
& \text { الإيجابـي، و البحث عن الدعم والتوجيـه، والتنفيس العاطفي لـدى العينـة } \\
& \text { تعزى للنوع الاجتماعي لصالح الإنـاث، و عدم وجـود فروق ذات دلالـة }
\end{aligned}
$$

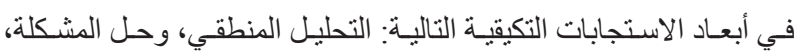

$$
\begin{aligned}
& \text { و التجنـب المعرفي، و الاستسـلام و الانسـحاب، و البحـث عـن حلـول بديلـة } \\
& \text { لـدى المو هو بيـن تعزى للنـوع الاجتماعي. }
\end{aligned}
$$

الكلمــات المفتاحيـة: الموهوبـون، الصلابـة النفسية، الاســتجابات التكيفيـة، الضغــوط النفسـية، الصـف الحسادي عثـر، دوبـة الكويــت. 


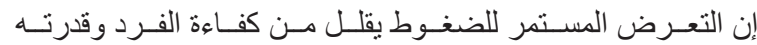
على التكيف، كمـا يقلـل مقاومتـهـ للضغـوط المختلفـة، الأمـر الذبي يعيـق عمليـات التكيـف النفسـي و الاجتماعـي لديـه، فتكـون النتيجـة في النهايـة الإصـابـة بمجمو عــة مـن الأمـر اض السيكوماتية (النفس جسـية)، والتهـي تكون ثمنـاً غاليـاً يدفعـه الفـرد نتيجـة التعرض المستمر للضغوط، وهذا مـا يسـمى باضطر ابـات التكيـف. وفي ضـوء ذلــ، تعبـر الاسـتجابات Coping Responses to Psychological التكيفيـة للضغـوط النفسيـية عن مجهودات يقوم بها الفرد بهدف التحكم في المو اقف Pressures الضـاغطـة، وتخفيـ الضيـق، وتعديـل الموقـف إلـى الأفضـل وصــ لاً إلـى المحافظـة قـدر الإمـكان على التـوازن الانفعالـي و التكيـف النفسـي

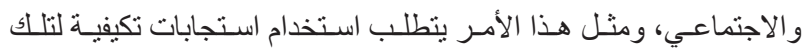

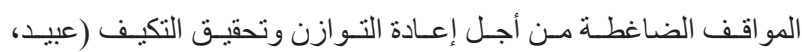

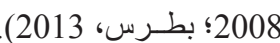

\section{أولاً: خلفية الدراسة وإطارها النظري الصلابة النفسية}

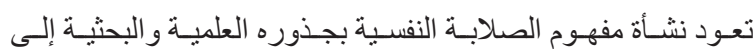
عالمـة النفس الأمريكيـة سـوزان كوباسـا التـي وضعـت الأسـاس لمفهوم

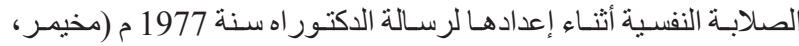
2012). وتـرى كوباســا أن العديـــــــن الأشـخاص يحتفظـون بمسـتوى

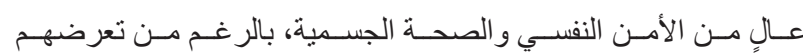
لأحـداث حياتيـة ضـاغطـة، الأمـر الذب يجعلنـا نعطي دور اً هاماً لثـخصية الفرد بـكل جو انبهـا، و هـذه النتيجـة لفتـت الأنظـار إلى الاهتمـام بضـرورة فحص مصـادر مقاومـة الضغوط؛ أب فحص تلـك العوامـل و المتغيـر ات التي تسـاعد الأفر اد على التو افق مـع الأحـداث الضـاغطـة المختلفـة التي

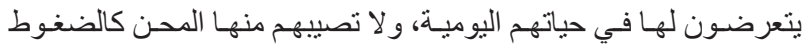

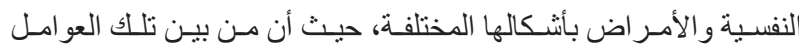

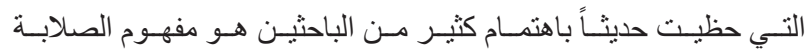

النفسـية (Kobasa, Maddi \& Kahn, 1982).

أشـارت كوباســا Kobasa (1979) إلـى أن الصلابــة النفسـية

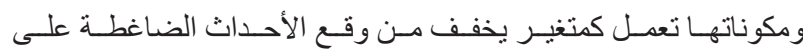

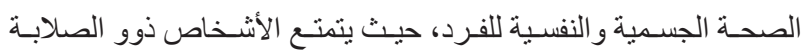
النفسية المرتفعـة بقدرة عاليـة على تحمـل الضغوط، وذلكـ لأن الصلابـة النفسـية تعـدـ بمثابـة الـــرع الواقـي و الجـدار المنيـع الــي يسـاعد الفـرد

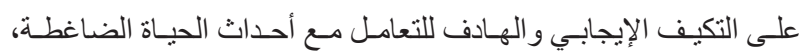
و هـي تـؤدي إلى تحقيـق الثـخصية القويـة القـادرة على احتــال الضغوط

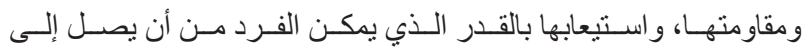
أقصـى درجـات التوافـق النفسـي، وتحقيـق خطواتـهـ الإيجابيـة نحسو

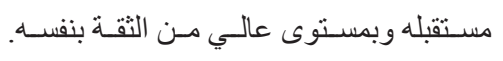

تتعـدد أبعـاد الصلابـة التي تـم استتنتاجها مـن خـلال سلسـلة در اسـات

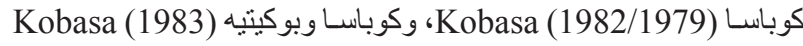

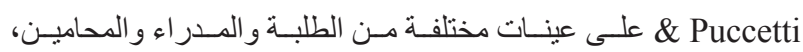

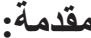

تعـد الصلابـة النفسية Psychological Hardiness مـن المفاهيم التي دخلت حديثـا إلى حقل علم النفس، وكانت بدايـة ظهوره على يـ عالمـة النفس الأمريكيـة كوباسـاسKabasa و التي استتندت في بلـورة هذا المفهـوم إلـى الفلسـفة الوجوديــة و أفـكار نظريـات علـم النفس المعرفيـة

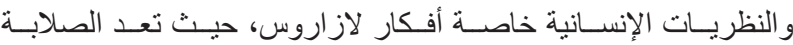
النفسية مـن أهم سـمات الثـخصية التي يمكن أن يكون لهـا دور إيجابي وقوي في مو اجهـة الضـــوط و التعامـل معهـا (مخيمـر، 1997).

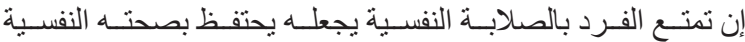

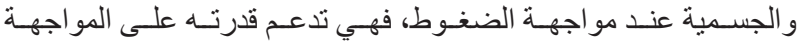

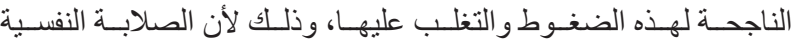
تلعب دور الوسبط بيـن التقييم المعرفي للفرد للتجــارب الضـاغطـة وبيـن الاستعداد و التجهيز لاستجابات التكيف، ومثنل هذه الآليـة يفترض أنها تخفض مسـتوى الضغـوط النفسـية للتجـارب التـي يمـر بهـا الفـرد، كمـا أنهـا تسـاعد الفرد على التعامـل مـع الضغـوط بفعاليـة (عبـاس، 2010). تتبايـن قـدر ات الأفـر اد فـي التعامـل مــع الضغــوط النفسـية تبعــا

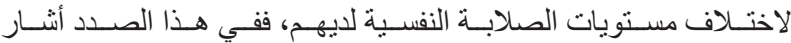
هانتـون Hanton إلـى أن الفـرد الـذي يتمتـع بالصـلابــة النفسـية يسـتخدم

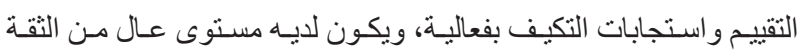
و أكثر قدرة على تقدير الموقف الضـاغط بأنـه أقل تهديداً، ويعمل على إعـادة بنـاءه إلـى شـيء أكثر إيجابيـة (ورد في عبـاس، 2010). فالضغط النفسي مـرض العصـر الحديث، ولـه آتـار على سـلوكيات

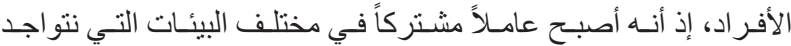
فيهـا، ومنهـا البيئـة التعليميـة التـي يو اجهـا الطـلاب (Sayiner, 2006).

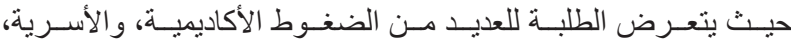

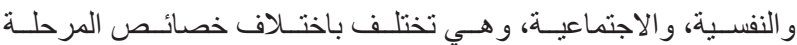
ومطالبهـا، وكذلــك باختـلاف خصائصهـم وسـماتهم التـي يتميـزون بهـا

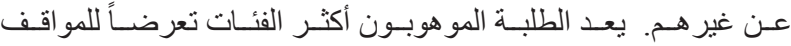
الضـاغطـة؛ لأنهـم يتميـزون بمجموعـة مـن السـمات و الخصائـص

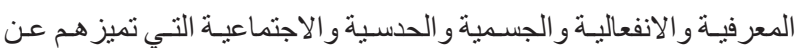

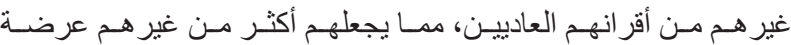

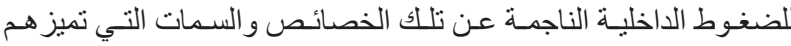
عن أقر انهم، و لا سـيما الضــوط الخارجيـة الناجمــة عـن البيئـة الأسـرية

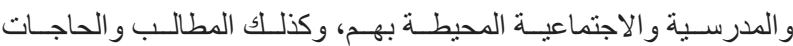
الكثيـرة التـي تفرضهـــا عليهـم المرحلــة النمائيــة ولاسـيما فـي المرحلـة

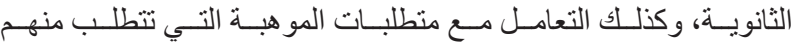
المزيــــــن الإسـتجابة لتلك المصــادر المختلفـة مـن الضغـوط و التكيـف معهـا (كو لانجيلـو وديفيز ، 2011/2003؛ الحربـي، 2011؛ السـمادوني، Clark, 2002; Chan, 2009; VanTassel- Baska, 2009)؛2014 
وزيـادة معـدل نبـض القلـب وارتفــاع ضغـــ الــدم، ومسـتوى السـكر، والآثـار النفسـية وتثـــل التعـب، والإرهـاق، والملـلـ، و انخفـاض الميـلـ للعمل، و الاكتئـاب و الأرق، و انخفـاض تقدير الذات، والآثـار الاجتماعيـة

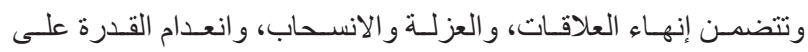

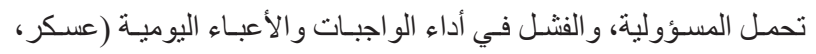
2003؛ عبيـد، 2008). (2008)

وعنــد النظـر إلـى مصــادر الضغــوط النفسـية للطلبـة الموهوبيـن

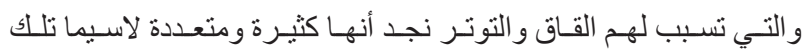
الناجمــة عـن طبيعـة مو هبتهـم ومتطلباتهـا و التـي تتمثـل بالآتـي: 1- الحساسية الز ائدة و المفرطـة وذللك بسبب عدم التجانس بيـن النضـج العقلـي و الانفعالـي، وبسـبب تأخـر النضـجـ الانفعالـي عـن النضــج العقلي، الأمـر الـذي يولـد لـدى الموهـوب ضغـوط نفسـية ولاسـيما و ويـه الز ائـد بكل مـا يتعامـل معـه مـن معلو مـات حسية، و الاستيعاب

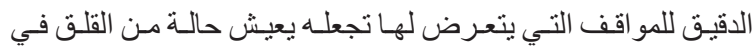
تقبلـه لنفسـه وللآخريـن. 2- النزوع نحـو الكماليـة والتي تعهـل على إثـعار الموهوب بعـدم الرضـا

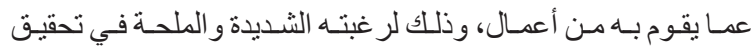

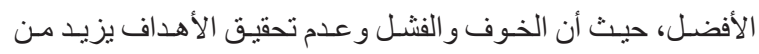
الضغـوط النفسية عليه.

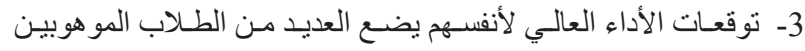
توقعـات عاليـة ومثاليــة لأنفسـهم، وبشـكل غيـر واقعـي، وهـــه

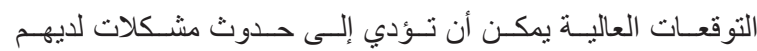
و لاسـيما عندمـا توجـد عو ائقق تحـول دون ذلـكـ. 4- الدافعيـة العاليــة لـدى المو هوبيـن نوعـاً مـن الحوافز الداخليـة تدفعهم نحو المزيــ مـن تحقيق الإنجـاز ات العاليـة، فالموهوبـون لايهم دافع قـوي وحافـز مـن أجـل تحقيـق الفئـة إنتاجيـة ابداعيـة عاليـة، ومثتل هذا الأمـر يتطلب التشـيع و التحفيز و المثابرة، ففي حـال عم توفر هـذه البيئة الداعمـة نتيجـة نقص أو ضعـف في الإمكانيـات الماديـة في البيــت أو المجتمـع، وبالتالـي فـإن نقصهـا يؤثر على الموهـوب

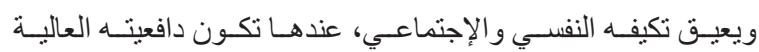

$$
\text { مصدر اً لمزيــ مـن الضنغوط. }
$$

5- التبايـن فـي معـدل النمــو بيـن المظاهـر النمائيـة المختلفــة التـي تتمثنل في عدم التوازن بيـن النضـج الانفعالـي وبيـن النــو العقلـي وهـذا ينعكس سـلباً على الاسـتعداد العـام لنمـو المو هبـة وتوظيفهـا

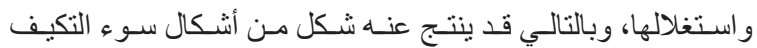

$$
\text { النفسـي و الاجتماعـي. }
$$

6- التوقعـات العاليـة للإنجـاز و عـدم قناعـة الأهـل و المعلميـن بمـا يصـل

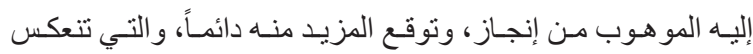

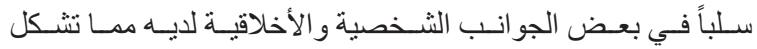

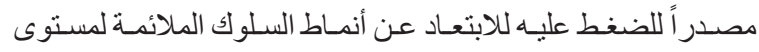

فهي تتكـون بتركيتهــا المتر ابطـة مـن ثنلاثـة مكونـات أساسـية وتنــل:

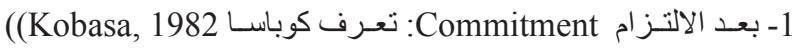

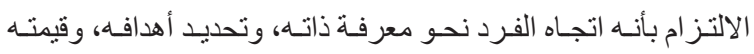
في الحيـاة، وتحملـهـ المسـؤولية، وهـو مـا يشـعر الفـرد بقيمـة وفائدة

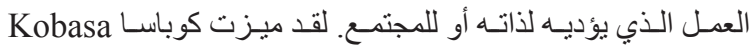
بيـن نوعيـن مـن الالتـزام ههـا: الالتـز ام نحسو الـذات: وعرفتهـ بأنـهـ

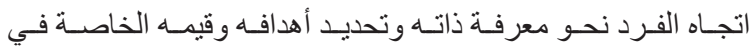
الحيـاة وتحديـــاتجاهاتـهـ الايجابيـة على نحـو يميززه عـن الآخريـن.

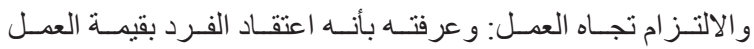

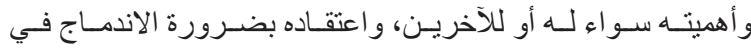
محيط العهل وكفاءتـهـ في انجـاز عمله، وضـرورة تحملـه مسئوليات العمـلـو الالتـز ام(Kobasa, Maddi, Puccetti, \& Zola, 1985). 2- بعـد التحكم Control : يشـير بعـد التحكم إلـى شـعور الفـرد بالقوة

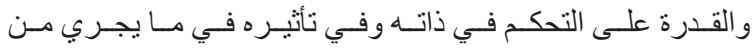

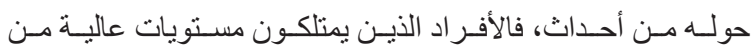
التحكم يكونـو ا قادرين على القيـام بـدور نشـــي حياتهم اليوميـة، ويظهـرون مسـتويات عليـا مـن الثــور بالمسؤولية تجـاه حياتهـم،

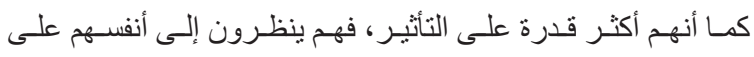

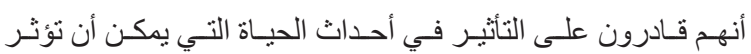

عليهم (Sinha \& Singh, 2009).

3- بعـد التحـدي Challenge: تعـرف كوباسـا (Kobasa, 1979) التحـدي بأنــه اعتقـاد الفـرد بــأن التغييـر المتجدد في أحـداث الحيـاة

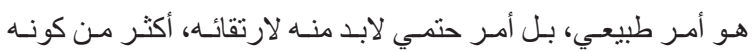

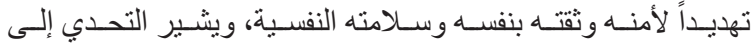
القدرة إلى النظـر إلى جميع الحـالات والمو اقف بايجابيـة مـع توقع نتائسج ناجحـة لهـا (Sinha \& Singh, 2009) .

\section{الاستجابات التكيفية للضغوط النفسية}

يعـد هانـز سـيلي Seley أول مـن تطـرق إلـى موضـوع ع الضغـط النفسي، بـل هـو يعـد أول مـن استخدم مصطلـح الضغط النفسي، فعرفـه

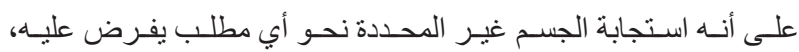

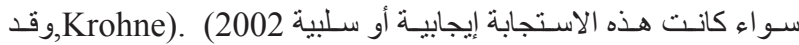
عـرف لاز اروس (Lazarus, 2003) الضغــوط بأنهـا مجموعـة مـن المثير ات التـي يتعرض لهـا الفرد، بالإضـافـة إلـى الاسـتجابات المترتبـة

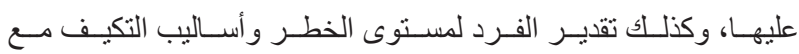
الضغـط. وينظـر إليـهـ كوهـن (Cohen) 2005, على أنسه خلـل مـدرك بين المطالب و الإمكانيـات يصاحبـه مجموعـة مـن المظاهر السـالبة مثل الغضــب و القـق والإحبـاط. ويثـير الباحثُون بمختلف اتجاهاتهم إلى وجهود الكثير مـن الآثـار السـلبية للضغوط النفسية، و التـي تشــل جو انب منعـدة مـن كيـان الفـرد

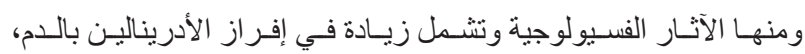




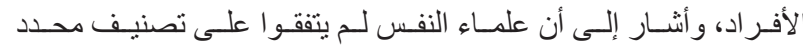
لاسـتر اتيجيات التكيـف مـع الضغـوط النفسية، و السـبب في ذلـك يرجـع

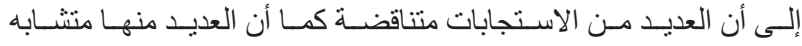
كذلك، لذلك فهو يـرى بوجـود ثـلاث مجمو عـات مـن التكيـف الأساسـية

1- الاسـتر اتيجيات التكيفيـة التـي تركـز علـى التقيهـم: وتشــل هــي الاسـتر اتيجيات التـي يتـم فيهــا تعديـل عمليـات التفكيـر المرتبطــة

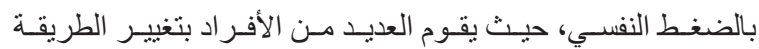
التـي يفكـرون فيهـا بالمشـكلة كفهـم المشـكلة بشـكل مختلـــ أو عـن طريـق تغييـر الأهــداف و القبـم الخاصــة بهـــ. 2- الاسـتراتيجيات التكيفيـة التـي تركـز على المشـكلة: تهـدف الاسـتر اتيجيات التي تركـز علـى المشـكلة إلـى التعامـل مـع سـبـ المثــكلة أو الضغــوط النفسـية، حبــث يقـوم العديــد مـن الأفـراد بمحاولـة تغييـر أو القضـاء على مصـدر الضغط النفسي وذلك عـن طريـق البحــث فـي سـبـب المثــكلة وتعلــم مهــار ات حلهــا. 3- الاسـتر اتيجيات التي تركـز على الانفعـال: وفي هـذه الاسـتر اتيجيات يقـوم الأفـر اد بتعديـل انفعالاتهـم التـي تصـاحـب الضغـط النفسـي عـن طريـق تحريـر أو تشـتيت أو إدارة حالتهم النفسية.

وقد أكد أللدو ونولين هوكوسيما (Aldao \& Nolen-Hoeksema,

$$
\text { 2010) على أسـلوبين مـن أسـاليب مو اجهـة الضغـوط هما: }
$$

1ـ الاسـتر اتيجيات الانفعاليـة في المو اجهـة: وتتمنتل في ردود انفعاليـة في مو اجهـة المو اقف الضـاغطـة، مثنل الغضـب، و التوترك، و الانزعـاج،

$$
\text { و القلـ و البـأس و العدوان. }
$$

2- الاسـتر اتيجيات المعرفيـة فـي المو اجهـة: وتتمثتل في إعـادة تفسـير، وتقويـم الموقفـ، و التحليـل المنطقـي، و النشـاط العقلي.

يتضــح بعـد الانتهـاء مـن اسـتنعر اض الأدب النظــري أن الصـلابـة النفسية تعتبـر مـن المتغيـرات ذات الأهمبـة الكبيـرة للثـخصية الإيجابيـة،

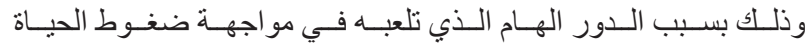
المختلفة التي يو اجهريا مختلف الأفر اد خاصــة الطلبـة الموهوبين، حيـث يو اجهـون ضنغـوط خاصــة بهـم تتعلـق بخصائصهـم العقليـة و الانفعاليـة، و الجســية، و الحدسية، و الاجتماعبـة التـي تميزهـم عـن الآخريـن، وهـا يولـد الحاجـة إلـى أهميـة الصلابــة النفسية لايهـم، إضـافـة إلـى حاجتهـم للاسـتجابات التكيفيـة الايجابيـة للتعامـل مـع هـه الضغـوط، بهدف زيـادة قدرتهم على التعايش مـع الضغـوط النفسية الذي يتعرضـون لهـا. وهـذا يعطـي أهميـة كبيـر لـكل مـن الصلابـة النفسـية والاسـتجابات التكيفيـة للضغــوط النفسـية لـدى المو هوبيـن، ومـن هنـا جـاءت الدر اسـة الحاليـة لتتنـاول موضــوع الصلابـة النفسـية و علاقتهـــا بالاســتجابات التكيفيـة للضغــوط النفسية لـدى الطلبـة المو هوبيـن.
عمـره الزمني في بعض الأنشـة و الألعـاب و الهو ايـات، مما بشـعره بالحرمـان، و الإحبـاط و العجـز عـن تلبيـة مثـل هـذه التوقعـات. 7- تعـدد الإهتمامـات حيـث ينخـرط المو هوبـون في أنشـطة واهتمامـات متعددة، وذللك لتنـوع هو اياتهم و اهتماماتهم وقدر اتهم، و هذا المعدل مـن الأنشـطة يثـكل مشـكلة بالنسـبة للموهـوب، فــع زيـادة الفـرص للإختيـار تصبـح عمليـة الإنتقـاء معقدة ومزعجـة، وهـذا مـا يـؤدي إلى شـعور المو هوبيـن بالحبـرة وعدم القدرة على الإختبـار الصـائب لمجـال در اسـة أو تخصـص معيـن، أو مهنـة مر غوبـة، ممــا يـؤدي إلـى دخولـه في المزيـد مـن الضغـوط. 8ـ ثقافـة وقو اعـــ المدرسـة التـي تشــير إلـى واقـع العديــــــن المـدارس إلىى أن الطـلاب المو هوبيـن ينظـر إليهم على أنهم معضلة للمدرسـة،

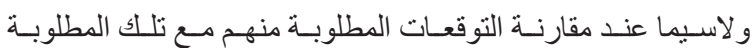
مـن أقر انهـم، ولصعوبـة اشـباع احتياجاتهم أحيانـاً. 9- علاقـة الموهـوب بأقر انـه نتيجـة للصفـات التـي يتميـز بهـا الموهـوب

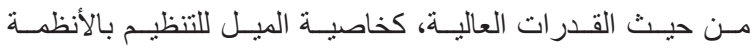
و القو انيـن و النز عـة القباديـة، قـد ينثـأ بينـهـه وبيـن أقر انـهـه في الفصـل مشـكلات وصر اعـات، ممــا قـد يثـعر أقر انهم بسـيطرة الموهـوب ". عليهـم ومسن ثـم نشـوء التوتـر بينهـم.

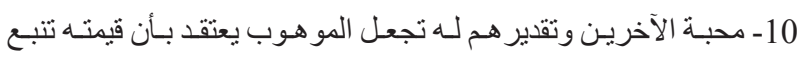
مـن مو هبتـه وليســ مـن شـخصيته، عندهـا يثـعر بأنـه إنسـان بـلا

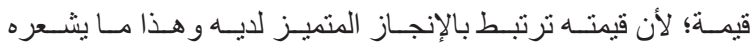
بالضغـطـ والتهديـد و الثـعور بعـدم الأمـان. 11- الضـــوط الاجتماعيـة تقــود الموهـوب إلـى شـعوره بالغضــب و الاسـتياء مـن ضغـوط وتسـلط الآخريـن وفرضهـم لآر ائهم عليـه،

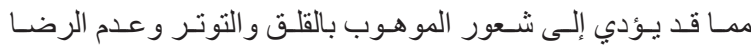
للانقيـاد إلى آر اء الآخريـن و الخضـوع لمتطلباتهـم (القرنـي، 2012؛ جـروان، 2013؛ أبـو أسـعد، 2014؛ VanTassel-Baska, 2009;

.(Malin \& Matthew, 2012; Bainbridge, 2014 لقـد بـدأ الاهتمـام بموضـوع الاسـتجابات التكيفيـة و علاقتهـا بالضغـوط النفسـية منــذ بدايـة سـتينات القـرن الماضــي، واسـتخدمت الدراســات مجموعـة مـن المصطلحسـات المر ادفــة للتعبيـر عنهــا مثــل: ســلوكيات التكيف (Coping Behaviors) أو جهود التكيف (Coping Efforts) أو مهـارات التكيـف (Coping Skills) أو اسـثراتيجيات التكيـف رئ (Coping Strategies)

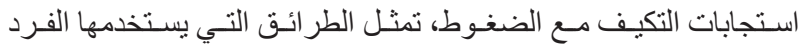

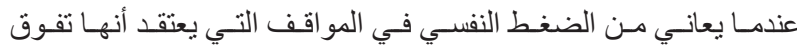
طاقته، بهدف التعايش مـع الضغطط النفسي الذي يتعـرض لـه و التخلص

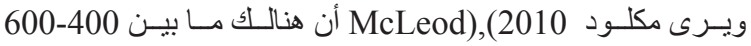
اســتجابة تكيفيـة للتعامـل مـع الضغــوط النفسـية يمكـن أن تظهـر لـدى 
على العلاقـات مـع الزمـلاء و الأسـرة، وفهم دور الإيمـان و المعتقـــات

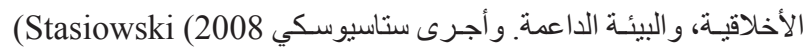

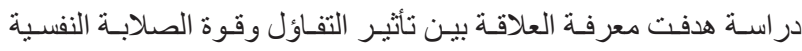
على إسـتر اتيجيات التكيف و الإجهـاد النفسـي، وتكونـت العينـة مـن (41)

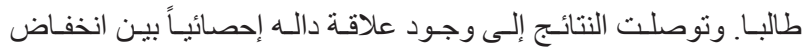

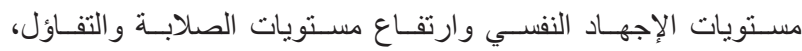
ووجـدت علاقـة إيجابيـة دالــة إحصـائيـاً بيـن اســتخدام إســتر اتيجيات

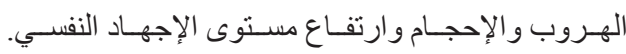

و هدفت در اسـة هارفتن Harvatin (2009) إلىى التحقق مـن علاقـة الصلابـة النفسية باسـتر اتيجيات التكيف لـدى طلبـة جامعـة كين في و لايـة

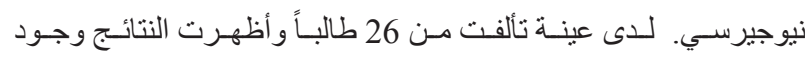
علاقـة إيجابيـة دالـه إحصائيـاً بين مستـوى الصلابة النفسية و استر اتيجيات

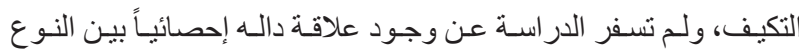
الاجتماعي و العلاقـة بيـن الصلابـة النفسية و اسـتر اتيجيات التكيف. و هدفت دراسـة غيث وبنـات وطقش (2009) إلى معرفـة مصسادر

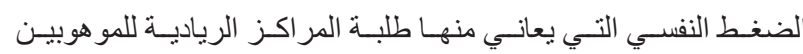

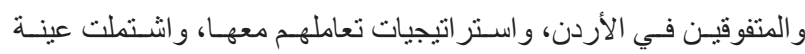

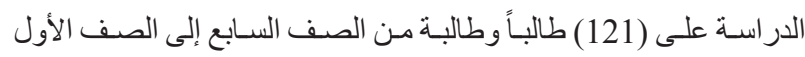

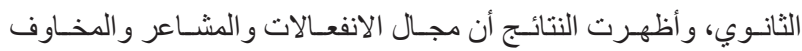

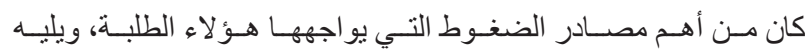

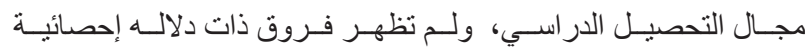

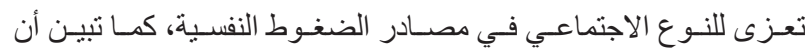
أكثر الاسـتر اتيجيات اســخداماً مـن قبـل هـؤل لاء الطلبـة في تعاملهـم مـع الضغوط هي: العدوان اللفظي و الجسـي، ثم الطر ائق المعرفيـة، و أقلهـا

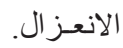

وهدفت در اســة كـروس وسـو ايتلك (2009) Cross \& Swiatek إلـى التعـرف علـى الاسـتجابات التكيفيـة الاجتماعيـة التـي يسـتخدمها

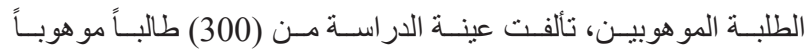

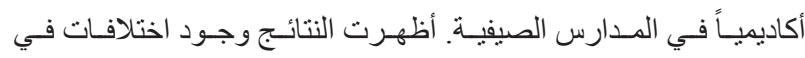

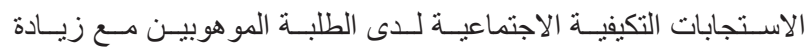
التحاقهم بالمــارس الصيفيـة، حيـث تبيـن أن الاسـتجابات التكيفـــة

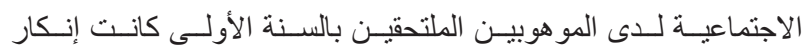
المو هبـة، وأن اسـتجابة التفاعـل الاجتماعـي كانـت أقـل شـيو عا بعـد ســنة

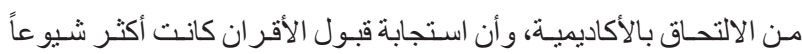
بعـد سـنة مـن الالتحـاق بالأكاديميـة.

و هدفـت دراسـة صــادق (2010) الكثـف عـن طبيعــة الفـروق بيـن الجنسـين فـي متغيـرات الصلابـة النفسـية، وتوضيـح العلاقـة بيـن

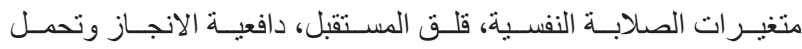
الغــوض، وتضدنـت عينــة الدر اســة (130) طالبـا مـن طلبـة الثنانويــة
ثانياً: الار اسـات السابقة

احريـت العديد مـن الدرسـات التـي تناولت الصلابـة النفسية و علاقتها ببعض المتغير ات، وكذلك الاستجابات التكيفيـة للضنوط النفسية ولـى عسـات مـن فئـات مختلفـة، ومـن بيئـات متتعدة، ففي هذا الصـدد. Morrissey \& Hanna (2001) سـعت در اسـة موريسـي وهانـا إلىى الكثـف عـن العلاقـة بيـن الصلابـة النفسـية وعـد مـن المتغيـرات،

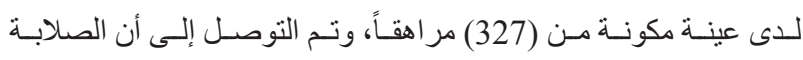

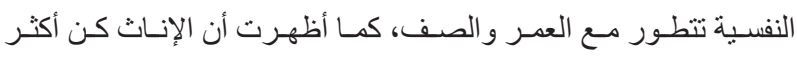
صلابـة مـن الذكـور في المسـتويات العمريـة المبكـرة. وقامـت سـوايتك بدر اسـة اسـتر اتيجيات التكيـف الاجتماعـي لـدى Swiatek (2001) الطـلاب المو هوبيـن فـي المرحلـة الثانويـة، تكونــت العينــة مـن (212)

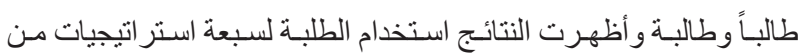
اسـتر اتيجيات التكيـف الاجتماعـي تتمثنل فـي: إنـكار المو هبـة، والدعابـة و الفكاهـة، و إظهـار مسـتوى عـال مـن النثــاط، و إنــكار التأثيـر السـلبي

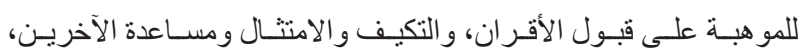
وخفض وتقليـل التركيـز على الثـهـرة.

Crowley, وهدفت در اســة كر اولـي و هايسـلب وهــادي (2003) إلـى الكثـف عـن دور الصلابـة النفسـية وتو افقهـا مـع أحـداث الحيـاة الضـاغطـة و إسـتر اتيجية مو اجهـة المو اقـف الصعبـة،

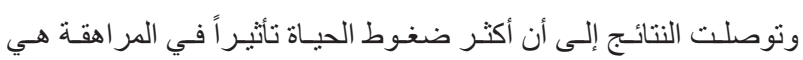
ضغوط العلاقـات، كمـا أنشـارت النتائسج إلى وجـود علاقـة ارتباطيـة دالـة

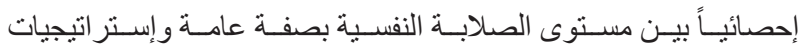
مو اجهـة أحـداث الحيـاة الضـاغطــة. وأجـرى بريسش ودوبــ Preuss \& Dubow (2004) دراســة بهدف التعرف على الاستر اتيجيات التكيفيـة للضغوط النفسية المدرسية و الضغـوط مـن قبـل الأقـر ان لـى الطلبـة المو هوبيـن، ومقارنتهـا بيـن عينـة المو هوبين و العاديين. و أنثـارت النتائتج إلى أن مستوى استر اتيجيات حل المشـكلات لمو اجهـة الضغــوط النفسـية ومسـتويات التكيـف الاجتماعي

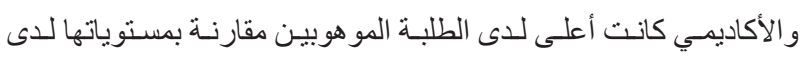
الطلبـة العاديين. و الادي.

وأجـرى باربـر مسارش Barber-Marsh (2007) در اســة بهـدف

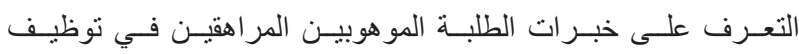

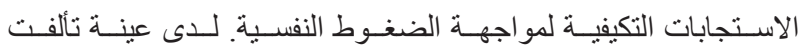
مـن (9) طـلاب مو هوبيـن في مرحلــة المر اهقـة، و أظهـرت النتائـج أن

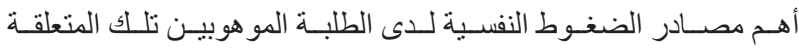

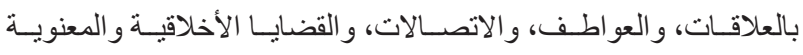

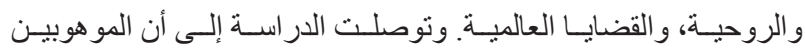

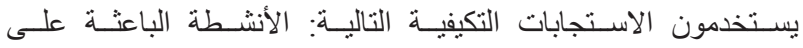

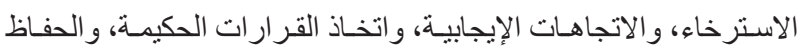


مـن اسـتر اتيجيات الكفــاءة الذاتيــة. و هدفـت دراسـة العبيدلـي (2012) إلـى التعـرف علـى مسـتوى

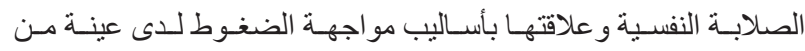

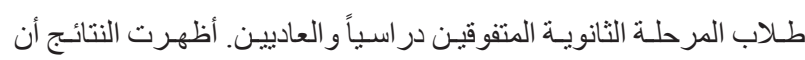
مسـتوى الصلابـة النفسية و أبعادهـا لـدى الطلبـة المتفوقيـن كان أعلى منــهـ لـدى العادييـن، كمـا أن المتفوقيـن اسـتخدموا أسـاليب المواجهـة الإيجابيـة

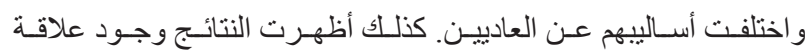

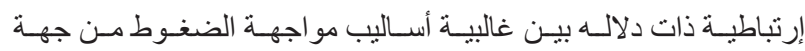
و الصلابـة النفسـية و أبعادهــا مـن جهــة أخـرى لـدى الطـلاب المتفوقيـن و العادييـن.

وأجـرى هنشيسـون وتيسـو (2014) Hutcheson \& Tieso در اسـة للتعـرف على الاسـتجابات التكيفيـة الاجتماعيـة التـي يسـتخدمها الطلبـة المو هوبيـن في المـدارس المتوســة والثانويـة، أظهـرت النتائـج

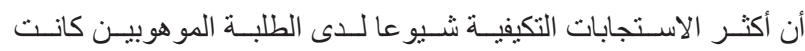
إيجـاد مجموعـات داعمـة مـن الأصدقـاء، و إخفـاء أو التقليـل مـن الهويـة، و المشـاركة في الأنشطة اللامنهجيـة، والبحـث عن الاعم مـن المعلمين، وتطويـر موهبـة الكتابـة و المو هبـة الموسـيقية.

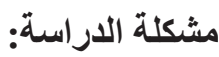
أثنـارت كلارك Clark, 2002$)$ إلـى أن المو هوبيـن يتميـزون عـن غير هـم فـي عـدد مـن الخصائـص المعرفيـة، و الانفعاليـة، و الجســية، و الحسسية، ونتيجـة لذلك تظهـر لديهم المشكلات و الضغوطسات التي تتبع

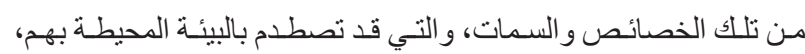

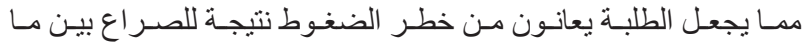

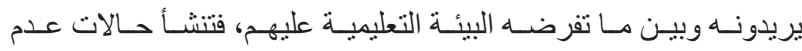
التكيف أو سـوء التو افق الناشـئ عـن الإخفـاق في الإشـباع.

فــن خـلال عمـل الباحتُة في الميـدان التربـوي لسـنوات لاحظـت حجــم الضغــوطو المشـكلات التـي تعتـرض الطلبـة و لا سـيما الطالبـات

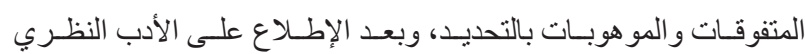

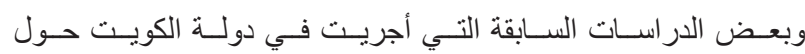

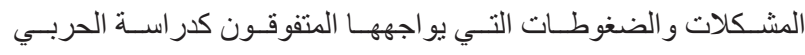
(2002) ودر اسـة المطيـري (2004) ودر اســة الدلمانـي (2007). وبنـاء

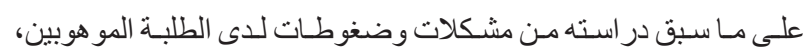
لوحظ أنـهـ لـم يتــم قيـاس مسـتوى الصلابـة النفسية، و الاستجابات التكيفيـة

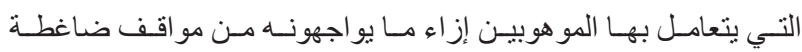
وكذلك در اسـة أهميـة التسـلح بالآليـات و المهـار ات و الاستجابات المناسبة

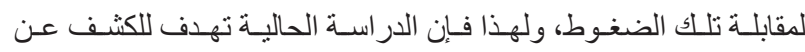
مسـتوى الصلابـة النفسـية و الاسـتجابات التكيفيـة للضغـوط النفسـية لـدى

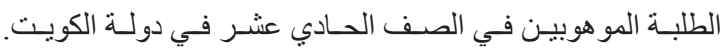

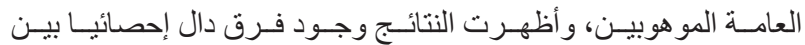
الطـلاب المو هوبيـن و الطالبـات المو هوبـات في الصلابـة النفسية لصالـح الطـلاب، ووجـود علاقـة ارتباطيـة دالــة موجبـة بيـن الصلابـة النفسـية وتحمــل الغـــوض.

وأجرترت الثـواف (2010) در اسـة هدفت إلى الكثـف عن الصلابـة النفسـية كمتغيـر معـدل بيـن القدر ات الإبداعيـة و الضغـوط النفسية لـدى

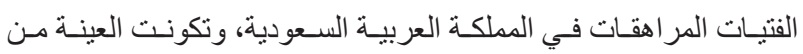
(339) طالبـة، وتوصلـت النتائـج إلىى عـدم وجـود ارتبـاط دال إحصائيـاً بيـن القدر ات الإبداعيـة والضغـوط النفسية، ووجـود ارتبـاط طـردي دال

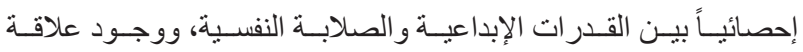
عكسـية دالــه الضغــوط الثـخصية و الاجتماعيـة و الضغنـوط التعليميـة و الصلابـة النفسـية. كمـا هدفـت در اســة دخـان و الحجــار (2007) إلـى التعـرف علـى

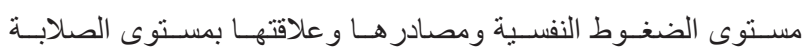
النفسية، إضـافـة إلى نتأثير بعض المتغير ات على الضغـوط النفسية لدى

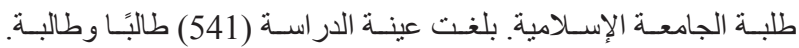

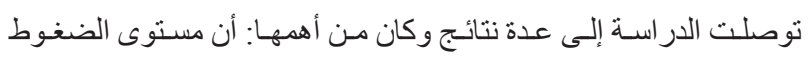
النفسية لدى الطلبـة كان (62.05\%)، و أن معدل الصلابـة النفسية لديهم كان (77.33\%)، وكان أعلى مسـتويات الصلابـة النفسـية هـو الالتـز ام بمعدل (80.76\%)، ثم التحكم بمعدل (77.30\%)، ثم التحدي بمعدل

وهدفت در اسـة البيرقـدار (2011) التعـرف على مسـتوى الضغـط

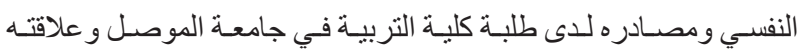

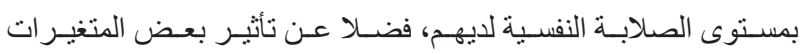

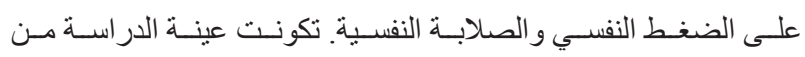

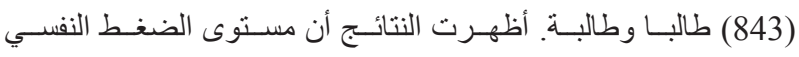

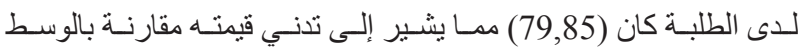
الفرضـي البالـغ (120)، وأن معدل الصلابـة النفسية لديهـ كان $(81,41)$

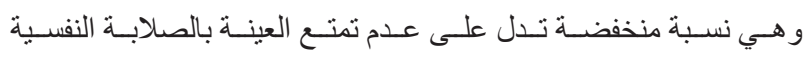

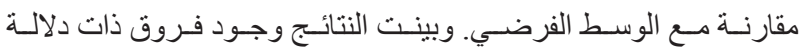

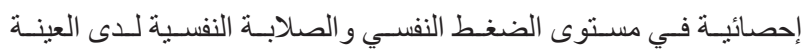
تعـزى لمتغيـر النـوع الاجتماعـي ولصـالـح الذكـور.

و أجرى يانـج 2012) (Yang در اسـة هدفت إلى التعرف على آنـار

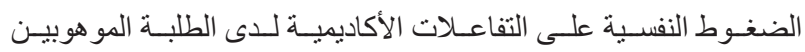

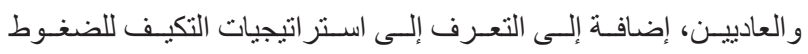

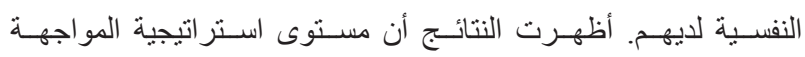

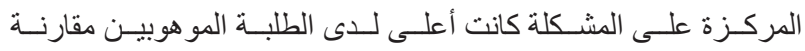
بمسـتو ياتها لـدى الطلبــة العادييـن، وكانــت مسـتويات الضغــوط النفسـية الأكاديميـة متدنيـة لـدى الطلبـة المو هو بيـن الذيـن أظهـرو ا مستويات عاليـة 


$$
\text { و الأسـرية، و النفسـية، و الاجتماعيـة . }
$$

4- يمكـن الاسـتفادة مـن نتائسج الدر اسـة فـي التخطيـطـ ووضـع البر امـج الوقائيسة و العلاجيـة لتسـهم في توجيـه و إرشـاد الطلبـة الموهوبيـن لرفـع مسـتوى الصلابـة النفسية وتحسـين مستوى التكيف النفسـي لديهـم.

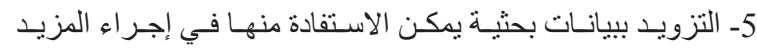

مـن البحـوث و الدر اسـات مسـتقبلاً.

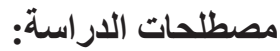

1- الصلابة النفسية Psychological Hardiness:

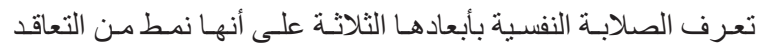
النفسي يلتززم بـه الفرد تجـاه نفسـه و أهدافـه وقيهـهـ و الآخريـن مـن حولـه، وهذا النمط يعكس اعتقـاد الفرد بأنـهـ قـادر على التحكم في مـا يلقـاه مـن أحـداث، ويتحمـل مسـئولية مــا يتعـرض لـه مـن أحـداث، وأن مــا يطـر أ علـى جوانـب حياتـهـهـ مـن تغييـر هـو أمـر ضــروري للنهـو أكثـر مـن

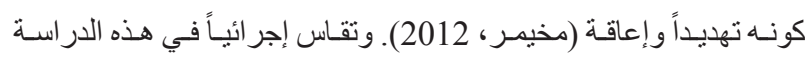

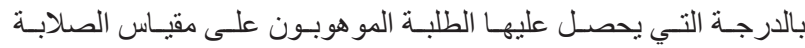
النفسية، و الذني يتكون مـن ثلاثـة أبعـاد و هي:الالتزز ام و التحكم و التحدي.

2- الاستجابات التكيفية Coping Responses: تعـرف الاســتجابات التكيفيـة علـى أنهـا مجموعـة مـن الأسـاليب و الوسـائل التـي يتصـدى فيهـا الفـرد للضغــوط ويتكيــف معهـا، ويكـون

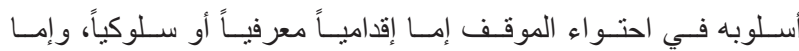

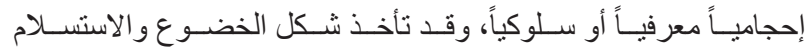
(Moss, 2004). وتقـاس إجر ائيـاً بالدرجـة التي يحصـل عليهـا الطلبــة المو هوبـون على أبعـاد مقيـاس الاسـتجابات التكيفيـة للضغــوط النفسـية الذي يتكون مـن ثمانيـة أبعـاد وهي:التحليـل المنطقي، التقييـم الإيجابـي، البحث عـن الدعم و التوجيـه، حل المشكلة، التجنب المعرفي، الاستسـلام و الانســاب، البحـث عـن حلـول بديلــة، التنفيـس (التفريــخ) الانفعالـي.

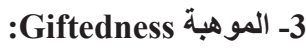

تتوعـت التعريفـات التـي تتاولـت المو هبـة بسـبب اختـلاف طـرق

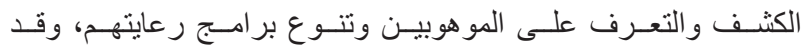
تبنــت الدر اســة تعريـــ رينزولـي للموهبـة مـن خـلال نمـوذج الحلقـات الثـلاث Renzulli's Three-Ring Model الـذي يؤكـد على أن السـلوك الموهـوب يعكس التفاعـل بيـن ثـلاث مجمو عــات مـن الســـات الإنسـانيةــ و هذه الخصائص هـي أن يكون ذا قدرة فوق المتوسط (ليس ليس

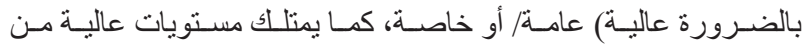
الالتـز ام بالمهوهـة (الدافعيـة)، ولديـهـ مسـتويات عاليـة مـن الإبـداع. الطلبـة المو هوبـون هـم أولئكلك الذيـن يمتلكـون أو هـم قـادرون على تطويـر هـذهـ

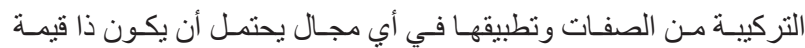
مـن الأداء الإنسـاني (Renzulli \& Reis, 2003). وتقـاس إجرائيـاً وفـق الدرجـة التـي يحصـل عليهـا الطالب في الأبعـاد الثلاثــة للمو هبـة التي وضعهـا رينزولي في تعريفهـ: (قدر ات عقلبـة عامـة فوق المتوسط
تتمثل مشكلة الدر اسة في الأسئلة التالية:

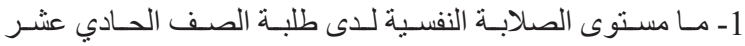
المو هوبيـن في دولـة الكويـت؟

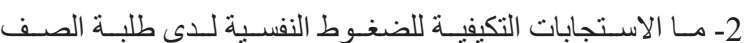
الحـادي عشـر المو هوبيـن فـي دولـة الكويـــ؟

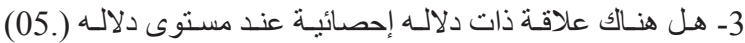
بيـن مسـتوى الصلابـة النفسـية و الاسـتجابات التكيفيـة لـدى طلبـة الصـف الحـادي عشـر المو هوبيـن في دولـة الكويـت؟

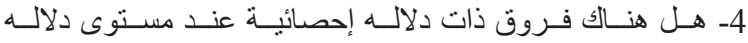
(05.) في مسـتوى الصلابـة النفسـية لـدى طلبـة الصـف الحـادي عشـر المو هوبيـن تعـزى للنــوع الاجتماعـي؟

5- هل هنـاك فروق ذات دلالـه إحصائيسة عند مستوى دلالـه (05. في الاسـتجابات التكيفيـة للضغـوط النفسـية لـدى طلبـة الصـف الحـادي عثـر الموهوبيـن تعزى للنوع ع الاجتماعي؟

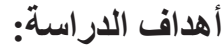
تهدف الدراسة الحالية إلى التعرف إلى: 1- مسـتوى الصلابـة النفسية لدى طلبـة الصـف الحسادي عشـر المو هوبيـن في دولـة الكويت.

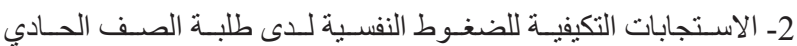
عشـر الموهوبيـن في دولـة الكويــــ. 3ـ العلاقـة بيـن الصلابـة النفسية و الاسـتجابات التكيفيـة للضغـوط النفسية لـى طلبـة الصـف الحسادي عشـر المو هوبيـن في دولـة الكويـت. 4ـ الفـروق فـي مسـتوى الصلابــة النفسـبة لـــى طلبــة الصـف الحـادي عثـر المو هوبيـن فـي دولــة الكويــت تبعـاً لمتغيـر النـوع عالاجتماعي. 5- الفروق في الاستجابات التكيفيـة للضغـوط النفسية لـدى طلبـة الصـف الحـادي عشر الموهوبين في دولـة الكويت تبعـاً للنوع ع الاجتماعي.

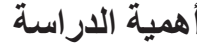

تكمن أهمية الدر اسة في عدة نقاط هي: 1- يعتبـر موضـوع الصلابـة النفسية مـن المو اضيـع التـي دخلت حديثـاً

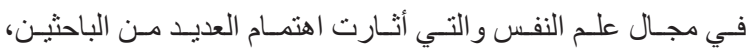

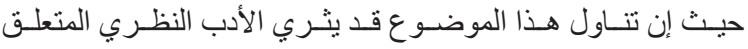
بالموضـوع ويـزود المكتبـة العربيـة بهذا الأدب ولاسـيما في دولــة

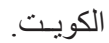
2- مـن المتوقـع أن تسـهم نتائُج الدر اسـة في تقديـم فهم نظـري لطبيعـة العلاقـة بيـن الصلابـة النفسـية و الاسـتجابات التكيفيـة لـــى الطلبـة المو هوبيـن فـي الصـف الحـادي عثـر بالمرحلـة الثانويـة في دولــة الكويــ.

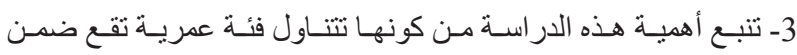

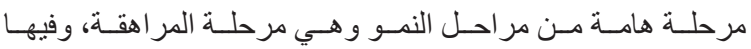

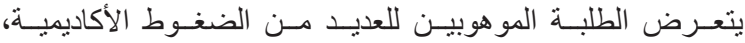




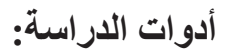

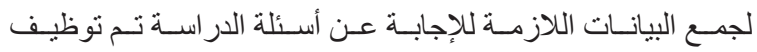

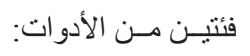

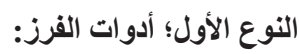

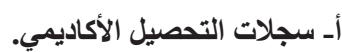

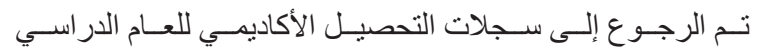

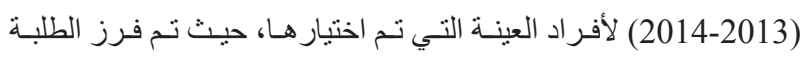

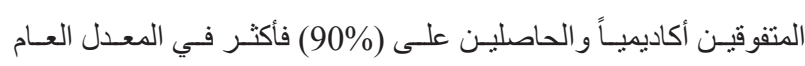

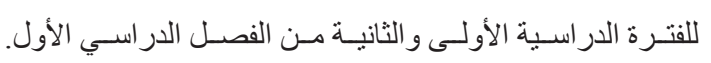

بـ اختبـار المصفوفــات المتتابعـة لرافـن Raven مسن إعـداد وتكييف عبدالـرؤوف (1999).

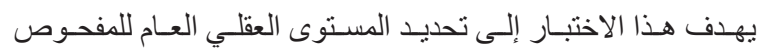

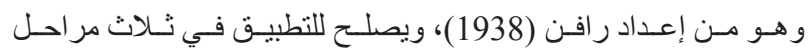
تعليمية (ابتائي - متوسط - ثانوي). يعتمد اختبار رافن للمصفوفات

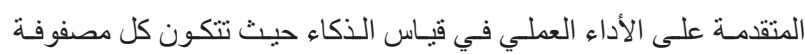

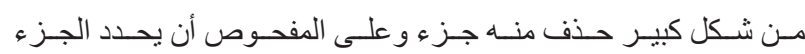
الناقص من بين (6) أو (8) أثكال تعرض عليه، ويتكون الاختبار من

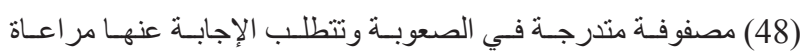

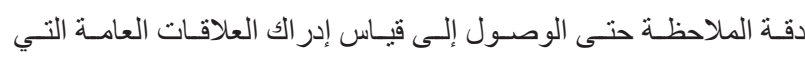
تتصـل بالجو انب العقليـة المجردة. قنـن الاختبـار على البيئة الكويتيـة مـن قبـل عبدالـرؤوف (1999)،

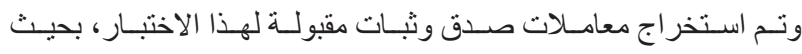

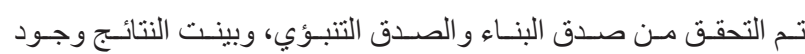
ارتبـاط ايجابي بلغت قيمتهـ (0.61) بيـن اختبـار المصفوفـات المتتابعـة

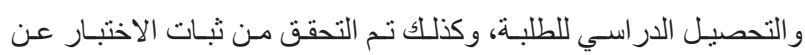
طريـق التطبيـق و إعـادة التطبيـق وكان معامـل ثبـات الاختبـار (0.87)، وبطريقة التجزئـة النصفيـة حيث بلـغ معامل الثبـات (0.90)، وبطريقـة ألفـا كرونبـاخ بلـغ معامـل الثبـات (0.89). لغايـات الدراســة تــم التحقـق مـن دلالات صـــق وثبــات اختبـار

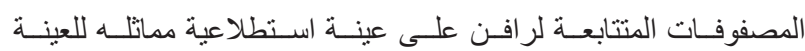

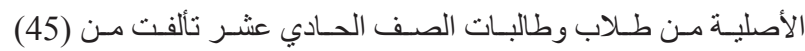

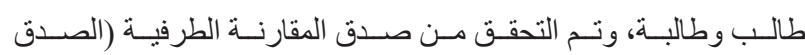

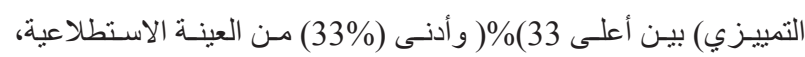

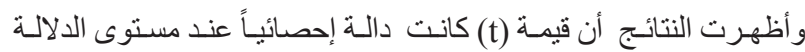

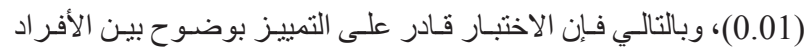

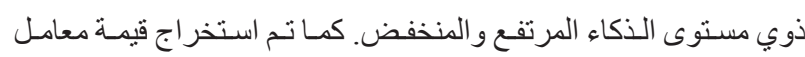
الارتبـاط بيرسـون(Person) بيـن درجـات اختبـار رافن، و التحصيـل

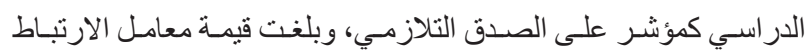
(0.73) وهي دالة إحصائياً عند مسنوى دلالـة (0.01). وتم استخراج

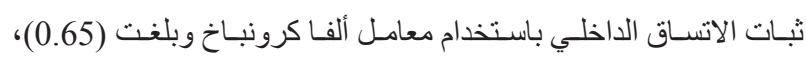

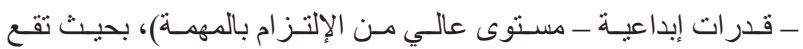

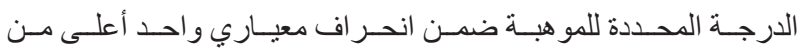
المنوسـط الكلـي للارجـات التائيسة.

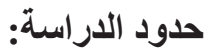

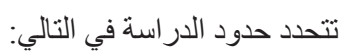
1- الحدود الزمانيـة: الفصل الدر اسي الثاني مـن العام الدر اسـي (2013-

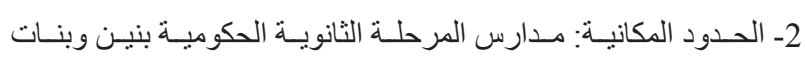

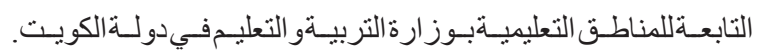

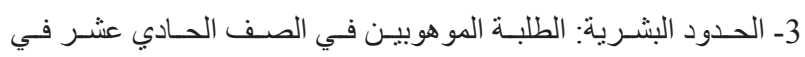

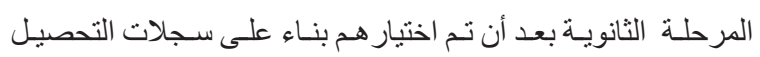

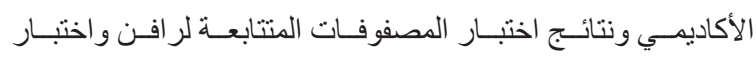

$$
\text { تور انس في الإبـاع. }
$$

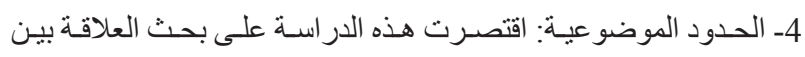

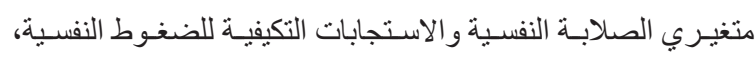
ولذلك انحصـرت نتائجهـا بهذه المفاهيـم.

\section{منهج الدراسة}

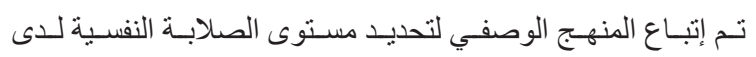

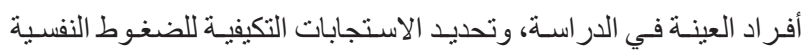

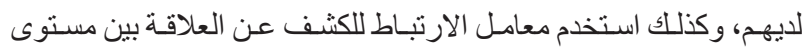
الصلابـة النفسية و الاستجابات التكيفيـة للضغوط النفسية.

\section{مجتمع الدراسة وعينتها}

تكسون مجتمـع الدراســة مـن جميعهم طلبـة الصـف الحسادي

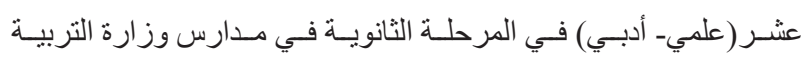

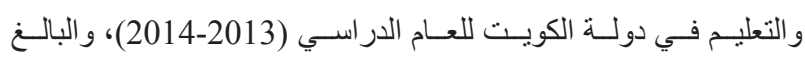

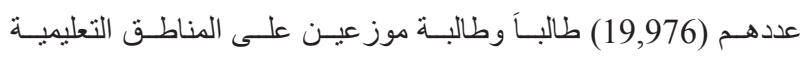

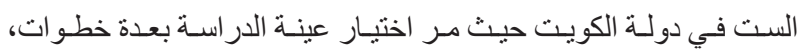

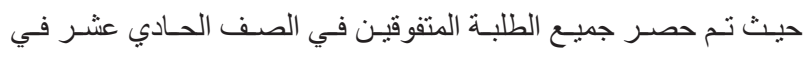

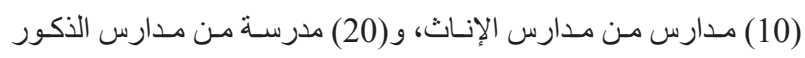

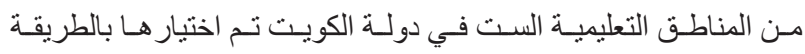

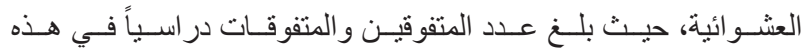

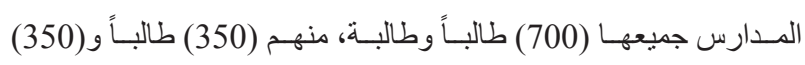

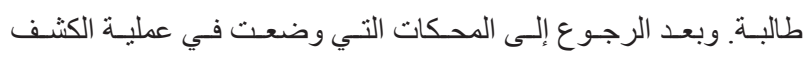

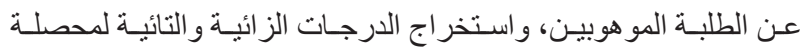

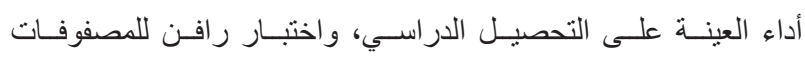

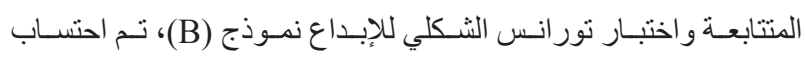

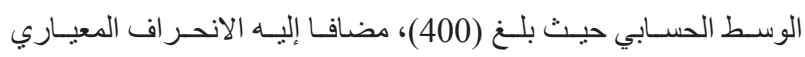

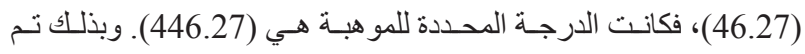

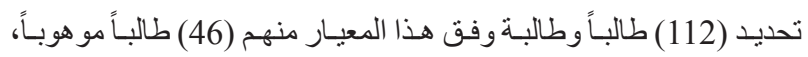
و(66) طالبـة مو هوبــة. 
النفس، وكذلــك إيجـاد الصـدق التلازمسي لـه مـع مقيـاس قـوة الأنـا مـن إعداد (ربيعع، 1978) وبـــغ معامـل الارتبـاط بينها (0.75) وهـو دال عندـ مسـتوى (0.01)، وبلغتت قيم معامـل ثبـات كل مـن: (الالتـز ام، التحكم، و التحدي)، (0.69، 0.76، 0.72) على الترتيب، ومعامـل ثبـات المقيـاس

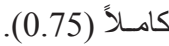

وتم التحقق مسن دلالات صـدق وثبـات مقيساس الصلابـة النفسية في

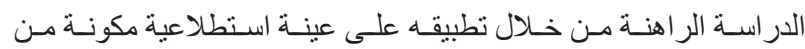

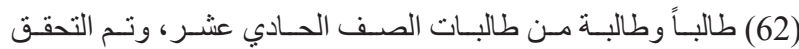
مـن صـدق التكويـن الفرضـي بحسـاب معامـلات الارتبـاط بيـن الأبعـاد المكونــة للمقيـاس و الدرجـة الكليـة و اتضــح أن قيـم معامـلات الارتبـاط

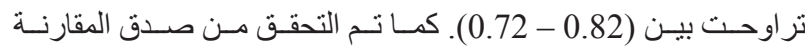

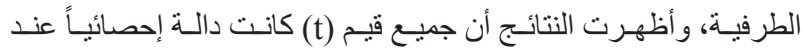

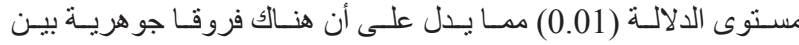

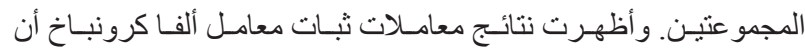

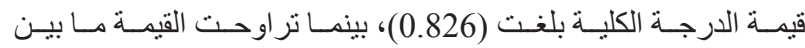

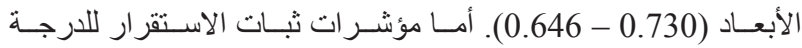

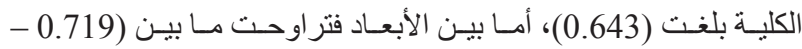

بـ قائمسة الاسـتجابات التكيفيـة للضغـوط النفسـية صورة-الثـباب

إعـداد (Moos, 2004).

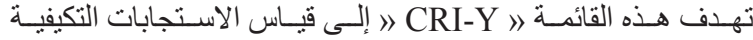

في التعامـل مـع الضغـوط فهـي تناسـب المـــى العهـري بيـن 12 -18

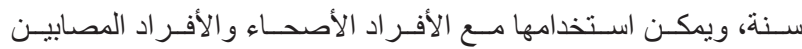
باضطر ابـات صحيـة، أو مـع مـن يعانـون مـن مشـكلات نفسية أو عاطفيـة

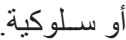

تم حسـاب ثبـات القائمسة في صورتهـا الأصليـة عن طريـق الاتسـاق الداخلي باسـتخدام معامـل ألفـا كرونبـاخ، وتر اوحت معامـلات الثبـات بيـن (0.55، و 0.71) للاككور ، وبين (0.59، و0.79) للإنـاث.

تم التحقق مـن الخصائُص السـيكومنرية للقائمـة في الدر اسـة الر اهنة مـن خـلال حسـاب مؤشـر ات صـدق المقارنــة الطرفيـة (الصـدق التمييزي) بيـن أعلى (33\%) ( و أدنـى 33\%) مـن العينـة الاستطلاعية (62) طالبـاً

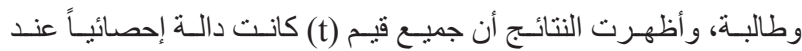

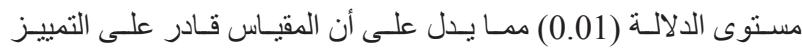

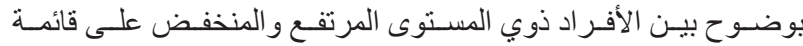

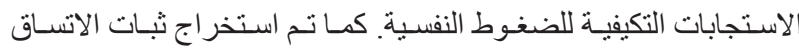

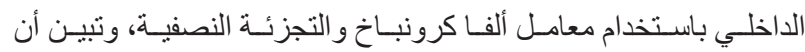
جميـع معامـلات الثبـات باسـتخدام معامـل ألفــا كرونبــاخ كانـت تتـر اوح مـا بيـن (0.757- 0.528)، وكذلك للتجزئسة النصفيـة تر اوحت مـا بيـن (0.580 0.809). و أظهرت نتائج ثبـات الاستقر ار (الثبـات بالإعـادة)
وباسـتخدام التجزئـة النصفيـة وبلغـت (0.70). كمــا تـم التحقق مـن ثبـات الاسـتقر ار وبلغـت قيمتـهـ (0.87).

ج- اختبـار تورانس Torrance الثـكلي لقيـاس التفكير الإبداعي

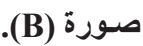

تـم إعـداد مقيـاس تور انـس للتفكيـر الإبداعـي فـي عـام (1966)،

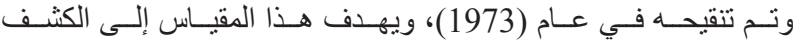
عـن الطلبـة ذوي التفكيـر والقـدر ات الإبداعيـة، ويتكـون الاختبـار مـن صورتيـن فر عيتيـن، الأولى الصـورة اللفظيـة: وتتكـون مـن سـتة أســلة استفسـارية حيـث يقوم المفحـوص بتخميـن الإجابـات الممكنة، و الثانيـة:

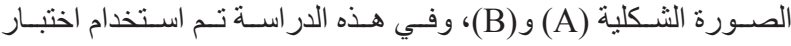
تور انس للتفكير الإبداعي الصـورة الثكلية (B)، الذي يتكون مـن ثلاثنة اختبـار ات فر عيـة يعطى فيهـا المفحـوص (10) دقائق ليجيـب على كل اختبـار ليصبـح مجموع وقت الاختبـار (30) دقيقة. وقد حساول تور انس في هذا الاختبـار أن يستثنير أبعـاد التفكير التباعدي المختلفة مـن (طلاقـة و أصـالــة ومرونــة وتفاصيـل)، وفـي عـام (2008) تـم تطويـر طريقــة تصحيـح الاختبـار لتتـــاول مهـار ات التفكيـر التباعـدي المختلفـة. اسـتخرجت الخصائُص الســيكومترية بالرجـوع إلـى دليـلـ اختبـار

Torrance Tests of Creative Think- تور انس في صورتـه الثكلية (ing (2008)، وتبيـن أن معامـلات الثبـات للقدر ات الإبداعيـة معامـلات مرتفعـة وذات دلالــة إحصائيـة، حيـث تر اوحـت معامـلات الثبـات بيـن .$(0.999-0.966)$

لغايـات أهداف الدر اسـة الحاليـة تـم التنأكد مـن دلالات صـدق وثبـات اختبـار تور انس لقيـاس التفكير الإبداعي على العينـة الاستطلاعية، حيث تم التحقق مـن صـدق التكويـن الفرضـي بحسـاب معامـلات الارتبـاط بين

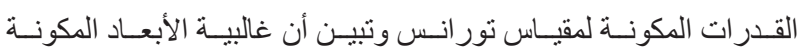

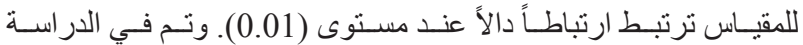
الحاليـة حسـاب معامل ثبـات الاختبـار بيـن المصححيـن ، و اتضـح أن قيم معامـل الثبـات بيـن المصححيـن تر اوحـت بيـن (0.941-1.000) وهـي

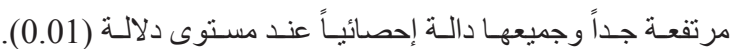
النوع الثاني؛ أدوات جمع البيانات، وتثثل: أـ مقياس الصلابة النفسية من إعداد مخيمر(2012).

هو مقيـاس يعطي تقديـراً كميـاً لصلابـة الفرد النفسية، ويتألف مـن فئن (47( فقرة تركز على جو انـب الصلابـة النفسـية للفـرد، وتقـع الإجابـة على فقـر ات المقيـاس في الاختيـار مـن ضدـن ثلاثـة مسـتويات (تنطبـق

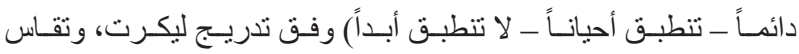

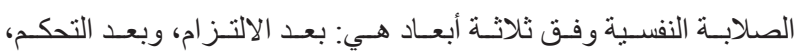
وبعـد التحـدي.

قـام مخيمـر بحسـاب الصــدق لـلأداة بطريقتــن: الصــدق الظـاهـري حيـث تم عرضـه على ثلاثـة مـن المحكميـن المختصبـن في مجـال علم 
بيـن المعلومـات ذات العلاقـة و غيـر ذات العلاقـة بموضــوع مـا، و القدرة

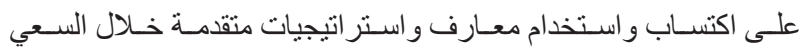

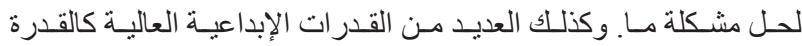

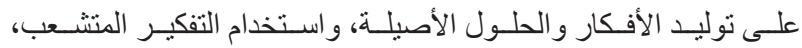
وتأجيـل الإغـلاق. و أخير اً التميز بخصائص الدافعيــة و المثابرة و الإلتنز ام بالمهيــات كامتــلاك مسـتويات عاليـة مـن قـوة التركيـز غيـر العاديـة، و المثابـرة و الهدفيـة في السـلوك أو النشـاط، و التوقعـات العاليـة للإنجـاز

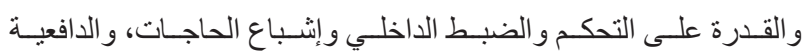
القويـة الناجمـة عـن شـعور قـوي بالحاجـة إلـى تحقيـق الـذات، الاهتمـام، و الحمــاس، الاصــر ار و العهـل الجـاد فـي ميـدان محـدد، الثقـة بالنفس، القـدرة على التعـرف على مشـكلات مهمـة فـي مجـال در اســة محـددة، وضـع معاييـر عاليـة لعملـل الثـخص، الانفتـاح على الخبـر ات والأفكار الجديـدة، الفضـــول، العـزم علـى الإقــدام علـى المخاطـرة، و الحساسـية للخصائـص الجماليـة (السـرور، 2010؛ جـروان، 2013؛ شـقير، Renzuli, 1979; Clark, 2002; Siegle patricia, 2000;؛2006 .( Renzulli \& Reis, 1997 يلاحظظ مـن خصائسص الطلبـة الموهوبيـن أنهـا تنســم بشـكل كبيـر مـع خصائُص الصـلابــة النفسـية بابعادهــا الثلاثــة مــن التـز ام وتحكـم وتحدي، فقد أكدت كوباسـا (Kobasa, 1982) ومـادي وكو هين و مـادي أن خصائسص مرتفهي الصلابـة Maddi, Kahn \& Maddi (1998)

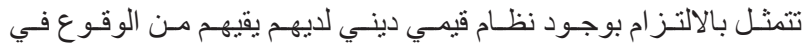
الخطـأ أو التعـرض للانحـر اف و الإدمـان أو الإصـابـة بالأمـر اض، و التميز

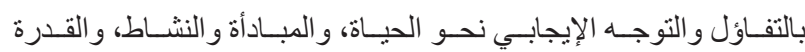

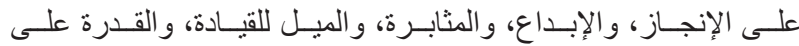
الصــود و المقاومـة، و اتخـاذ القر ار ات و الاختيـار بيـن عدة بدائلـ متعددة، و التحكم بالانفعـالات، و العمـل تحـت الضغـوط، و الثقــة بالنفس، الو اقعيـة و الموضو عيـة في تقييم الذات و الأحـداث و الأحـداث المستقبلية، الاتسـام

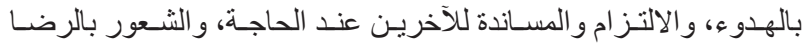
عـن الـذات، و الاعتقــاد بـان النجـاح في الحيـاة يعـود للعهـل و المجهـود، وليس إلى الصدفـة أو الحظظ أو الظـروف، والإتقان في العهل و الدر اسـة، و الاستففادة مـن خبرات الفشـل في تطويـر الذات، و القدرة على التجديــ والارتقــاء، و الرغبـة فـي استكثــاف البيئسة، ومعرفــة مـا يجهلونــه، و الاهتمـام بالبيئـة و المحافظــة عليهــا و المشــاركة الفعالـــة فيهـا، و اعتبــار

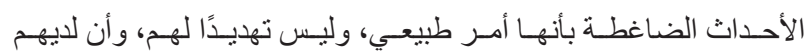
القـدرة على اقتحسام المشـكلات لحلهـا، وعـدم انتظــار حدوثهـا، وتوقـع

المشـكلات و الاسـتعداد لهـا.

و عنـــــارنــة نتائـج الدر اســة الحاليـة مـع نتائسج الدر اسـات السـابقة نجـد أن در اســة العبدلـي (2012) توصلـت إلـى نتائسج مشـابهة للار اسـة الحاليـة، حيث أثـارت نتائجها إلى ارتفـاع معدل الصلابـة النفسية لـدى

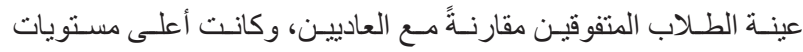

أن معامـلات الارتبـاط امتـدت مــا بيـن (0.817- 0.527) وكانـت ذات دلالــة إحصائبــة عنـــ مسـتوى دلالــة (0.01). نتائج الاراسة

1- النتائج المتعلقـة بسؤ ال الدراسـة الأول: للإجابـة عـن سؤال الدراســة الأول الـــي ينـص علـى: إ ماهـو مسـتوى الصلابـة النفسـية لـدى

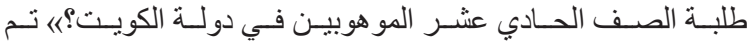
حسـاب قيـم المتوســات الحســابية، وقيــم الانحر افــات المعياريــة لارجـات الطلبـة المو هوبيـن في الصـف الحـادي عشـر على مقيـاس الصلابـة النفسـية كمـا هـو موضــح بالجـدول (1). جـدول 1. المتوسـطات الحسـابية و الانحر افــات المعياريــة لدرجـات الطلبـة المو هوبيـن على مقبـاس الصـلابــة النفسـية

\begin{tabular}{|c|c|c|}
\hline الانحر اف المعياري & المتوسط الحسابي & البعد \\
\hline 8.48 & 82.18 & الالتزام \\
\hline 8.57 & 77.80 & التحكم \\
\hline 9.45 & 78.03 & التحدي \\
\hline 7.28 & 79.37 & لدرجة الكلية \\
\hline
\end{tabular}

يتبين مـن الجدول(1) أن قيمـة المتوسط الحسـابي للارجـة الكليـة مرتفعـة وبلغـت (79.37) بانحــر اف معيـاري (7.28). وفيمـا يتعلـق بأبعـاد

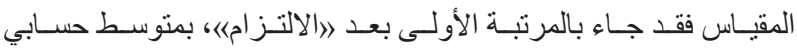

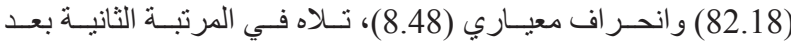

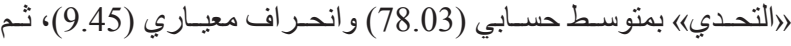
في المرتبـة الثالثة بعد 》التحكم)《، بمتوسط حسـابي (77.80) و انحر اف

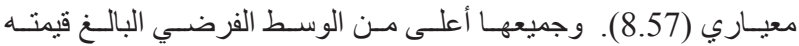

تظهـر النتائج أن مسـتوى الصلابـة النفسية للدى طلبة الصـف الحادي عثـر المو هوبيـن في دولــة الكويــت كان مرتفعـا، وأن أعلى مسـتويات

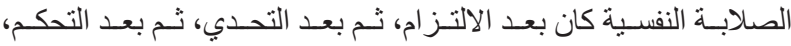
فارتفـاع الدرجـة الكليـة للصلابـة النفسية نابـع مـن ارتفـاع الأبعـاد الثلاثـة

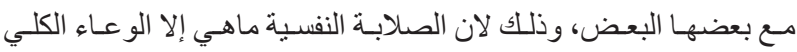

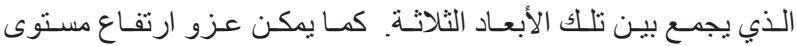
الصـلابـة النفسـية لــدى أفـر اد العينـة مـن كونهـم طلبـة مو هوبيـن فـي الصف الحـادي عشـر، حيث أنهم يتصفون بخصائص وسـمات محكات

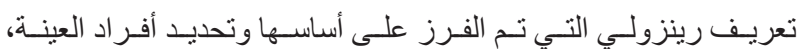
و التـي تتمحسور في القدرة فـوق المتوسط (الـذكاء)، والقدرة الإبداعيـة، و الإلتزز ام بالمهات(الدافعيـة). و ونتيجـة لذلك نـرى أنهم تميزو ا في العديــ مـن الخصائص المعرفيـة (العقليـة) التـي تتمثنل في مستويات عاليـة مـن

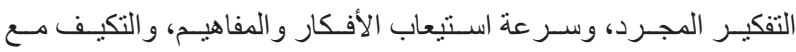
المو اقـف الجديـدة، و القـدرة غيـر العاديـة علـى التعامـل مــع المعلومــات ومعالجتهــا واسـتـعادتها بطريقـة دقيقـة وسـريعة، والتطبيـق للقـدر ات

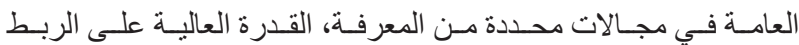




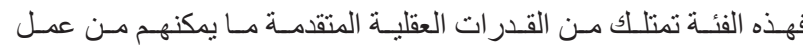
تحليـل منطقي عنــ تعرضهم لمصـدر مـن مصـادر الضغـوط النفسـية، وكذلك قدرتهم على توظيف استر اتيجيات حل مشـكلة في التعامل مـع التحديـات التي تواجهرم في الحيـاة. أكدت جميع النظريـات و الدراسـات

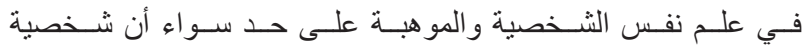
المو هـوب تتسـم بسـمات معينـة تختلـف عـن تلــك التـي لـدى العادييـن، فهم أكثر جـر أة في مواجهة التحديـات؛ وهـم أكثر إدر اكاً للمواقف وهـم

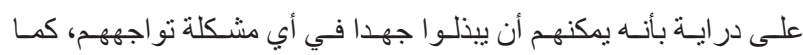

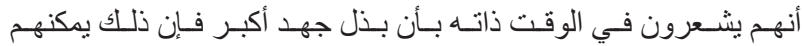
مـن إنتاج عمل جيد مفيد، ويمكنهم حلـ المشكلات ومو اجهـة التحديـات

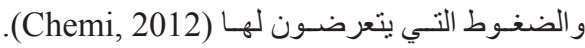
أثنـارت كلارك (Clark, 2002) إلى أن الطلبـة المو هوبين يتميزون بالظهـور المبكـر لأنـــاط متمايـزة مـن المعالجـة الفكريــة مثـل التفكيـر المتشـعب وتحسـس المترتبـات و التعميمـات و اسـتخدام القيـاس و التعبيـرات المجردة، وقدرة غير عادية على المعالجة الثـاملة للمعلومات، و السـرعة و المرونـة فـي عمليـات التفكيـر ، وقـدرة مبكـرة علـى تأجيـل الإغـلاق،

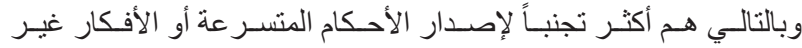
الناضجـة، وكل هذه الصفـات تتعكس في تعاملهم مـع الضغـوط النفسية

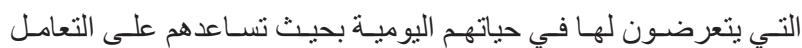
بايجابيـة مـع مصــادر هـذه الضغــوط وتحليلهـا وتقييمهـا و التصـدي لهـا بموضو عيـة بــلا مـن أن يستسـلمو الهـا. وقـــ توصلـت در اســة سـو ايتكا Swaitek (2001) إلـى أن الطلبـة المو هوبيـن غالبـاً مـا يسـتخدمون سـبع اسـتر اتيجيات تكيفيـة مـع البيئـة و الأفـر اد المحيطيـن بهـم و هـي: إنـكار المو هبــة، و الدعابــة و الفكاهــة، و إظهار مسـتوى عاليـاً مـن النشـاط، و إنـكار التأثير السـلبي للموهبـة على قبـول الأقران، و التكيف و الاتصـال ومســاعدة الآخريـن، وتقليـل التركيز Hutcheson \& Tieso,) على الثـهرة. أمـا در اسـة هو تشـيون وتيسـو

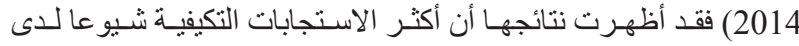
الطلبـة المو هو بيـن كانت إيجـاد مجمو عـات داعمـة مـن الأصدقـاء، و إخفـاء

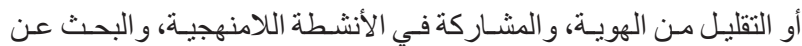

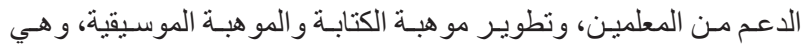
تتشـابه نو عـا مـا مـع بعـض الاسـتر اتيجيات التكيفيـة للدى عينـة الدراسـة

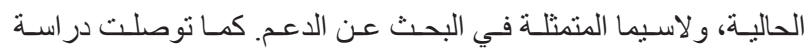
بابر مـارش (Barber-Marsh, 2007) إلى وجـود استر اتيجيات تكيفيـة

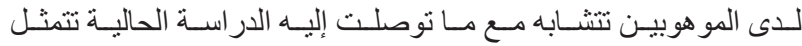
في الأنشـة الباعثـة على الاسـترخاء، و الاتجاهـات الإيجابيـة، و اتخــاذ

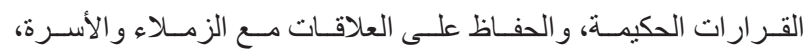

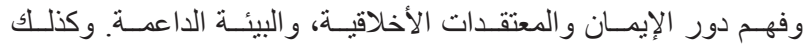
در اســة Yang, 2012$)$ (إلـى نتيجـة مشــابهة لنتيجـة الدر اســة الحاليـة

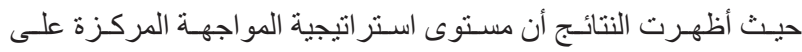

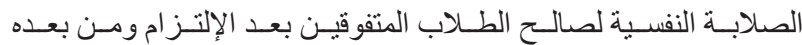
التحكـم و أخيـراً بعـد التحـدي، وهـي تتشــابه مـع ترتيـب أبعـاد الصلابــة النفسـية فـي الدر اسـة الحاليـة لـدى عينـة المو هوبيـن. و وكذلــك دراسـة الثــواف (2010) التــي أوجـدت ارتبــاط طــردي دال إحصـائيـاً بيـن

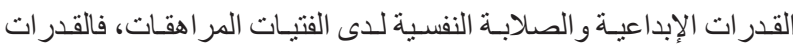
الإبداعيـة لديهـن رفعـت مـن مسـتوى الصلابـة النفسـية. 2- النتائج المتعلقـة بسؤال الدر اسـة الثاني: للإجابـة عـن سؤال الدر اســــ

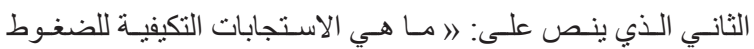
النفسـبة لــدى طلبـة الصـف الحـادي عشــر المو هوبيـن فـي دولــة الكويــ؟؟ نـم حسـاب قيـم المتوسطـات الحسـابية، وقيـم الانحر افـات المعياريـة لدرجـات الطلبــة الموهوبيـن على قائمــة الاســتجابات التكيفيـة للضغـوط النفسـية كمـا هـو موضـح بالجدول (2). جدول 2: المتوسطـات الحسـابية، و الانحر افـات المعياريـة، لدرجـات الطلبـة المو هوبيـن على قائمسة الاسـتجابات التكيفيـة للضغـوط النفسية

\begin{tabular}{|c|c|c|}
\hline الانحر اف المعياري & المتوسط الحسابي & 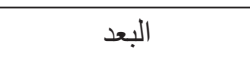 \\
\hline 13.24 & 74.40 & التحليل المنطقي \\
\hline 16.78 & 64.78 & التقبيم الايجابي \\
\hline 22.57 & 46.63 & البحث عن الدعم \\
\hline 19.77 & 67.16 & حل المشكلة \\
\hline 18.19 & 51.44 & التجنب المعرفي \\
\hline 19.30 & 48.61 & الاستسلام و الانسحاب \\
\hline 18.81 & 53.67 & البحث عن حلول \\
\hline 21.15 & 42.66 & التنفيس العاطفي \\
\hline
\end{tabular}

يتبيـن مـن الجـدول (2) أن أعلـى مسـتوى مـن الاســــابات التكيفيـة

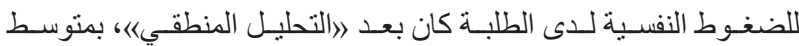
حسـابي (74.40) بانحـر اف معيـاري (13.24)، تـلاه في المرتبـة الثانيـة

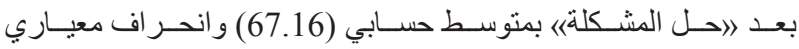

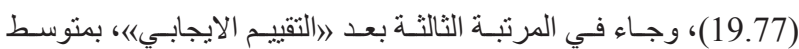
حسـابي (64.78) و انحـر اف معيـاري (16.78)، ثم في المرتبـة الر ابعـة بعـد 》البحـث عـن حلـول بديلـةنة) بمنوسـط حسـابي (53.67) و انحـر اف

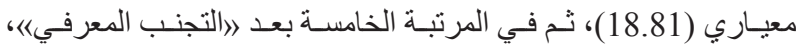

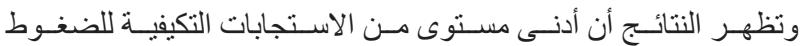
النفسية لـدى طلبـة الصـف الحسادي عشـر المو هوبيـن كان بعــ 》التنفيس

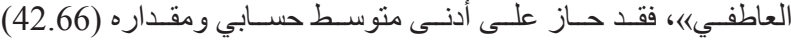
بانحــر اف معيــاري (21.15). ويمكن تفسير حصـول الاستجابات التكيفيـة للضغوط النفسية التاليـة التحليل المنطقي، ثم حلـ المشكلة، ثم التقييم الايجابي على منوسطات

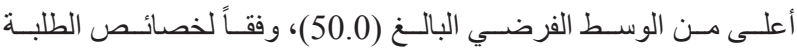
المو هو بيـن حيـث تتمتـع هـذه الفئـة مـن الطلبـة بخصائص غيـر عاديـة؛ 
بعـد التحـدي ببعـد حـل المشكلة وبلغـت قيمتـه (451.)، ثم بعـد التحكم ببعـد حـل المشـكلة وبلغـت قيمتـه (410)، ثـم علاقـة بعـد الالتـز ام ببعـــ التحليـل المنطقي وبلغـت قيمتهـه (338).

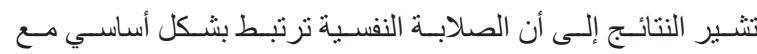
الأبعـاد الايجابيـة مـن الاسـتجابات التكيفــة، ويمكن تفسـير هـذه النتيجـة مـن حيـث أن الاسـتجابات التكيفيـة الأربـع المذكـورة و الصلابـة النفسـية
المشـكلة كانت أعلىى لـدى الطلبـة المو هوبيـن مقارنـة بمسـتوياتها لــى الطلبـة العادييـن.

3- النتائج المتعلقة بسؤال الدر اسـة الثالث: للإجابـة عـن سؤ ال الدر اســة الثالث الذب ينص على 》هـل هنـاك علاقـة ذات دلالـه إحصائيـة عند مسـتوى دلالـه (.05) بيـن مسـتوى الصـلابــة النفسـية والاسـتجابات التكيفيـة لـدى طلبـة الصـف الحـادي عشـر المو هوبيـن فـي دولــة

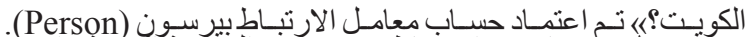

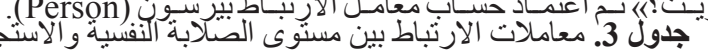

\begin{tabular}{|c|c|c|c|c|}
\hline \multicolumn{4}{|c|}{ الصلابة النفسية } & \multirow{2}{*}{ الاستجابات التكيفية } \\
\hline الدرجة الكلية & | التحدي & التحكم & الالتز ام & \\
\hline$* * 325$ & $* 226$ & $* * 243$ & $* * 338$ & التحليل المنطقي \\
\hline$* * 312$ & $* * 267$ & $* 198$ & $* * 303$ & التقييم الايجابي \\
\hline$* 225$ & $* 193$. & 0.041 & $* * 313$ & البحث عن الدعم و التوجيه \\
\hline$* * 545$ & $* * 451$ & $* * 410$ & $* * 485$ & حل المشكلة \\
\hline-0.157 & -0.183 & -0.153 & -0.047 & التجنب المعرفي \\
\hline$* * 312 .-$ & $* * 312 .-$ & $* * 300 .-$ & -0.155 & الاستسلام و الانسحاب \\
\hline 0.079 & 0.109 & 0.04 & 0.041 & البحث عن حلول بديلة \\
\hline 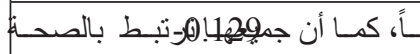 & 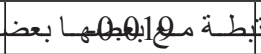 & 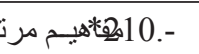 & -0.105 & التنفيس العاطفي \\
\hline
\end{tabular}

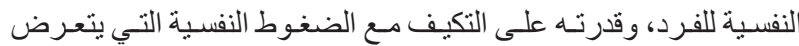
لهـا الفرد، إذ يشـير مفهوم الاستجابات التكيفيـة إلى مجموعـة مـن أنمـاط

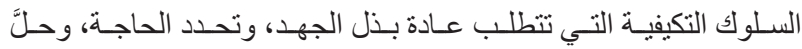

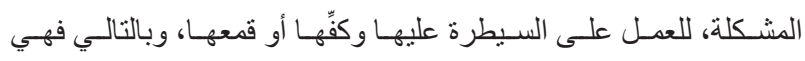
تسـتخدم بمرونـة كافيـة كلمـا نطلـب الموقف الضـاغط (عـودة، 2010). في حيـن أن الاسـتجابة التكيفيـة التـي تركـز على حـل المشـكلة تهـدف

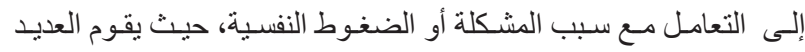

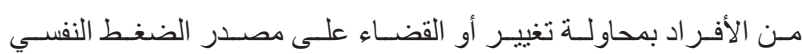
McLeod,) عن طريـق البحث في سبب المشكلة وتعلم مهـار ات حلهـ 2010)، كمـا يهـدف التحليـل المنطقي إلـى محاولـة الفهم و التهيؤ الذهنـي للموقف الضاغـط ومترتباتـه، فـي حيـن يسـعى الفـرد في اسـتر اتيجية

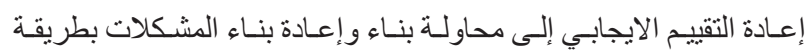
ايجابيـة مـع اسـتـمر ارية تقبـل الو اقـع فـي الموقف الضـاغــ (الضريـي، 2010). إن مفهوم الصلابـة النفسـية لا يختلف في دلالاتـهـ عـن مفهوم الاسـتجابات التكيفيـة الايجابيـة إذا يثــير مفهـوم الصـلابــة النفسـبة إلـى لـى معتقدات الفـرد عـن فاعليته،ه، وقدرتـهـ على الإدر الك الحقيقي، و التفسـير الو اقعي، و الموضوعي، و المنطقي لضغـوط أحداث الحيـاة، ومو اجهتهـا

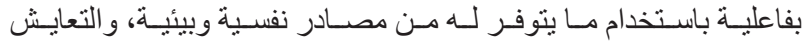

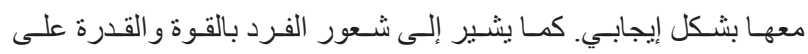

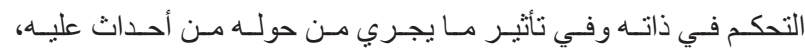

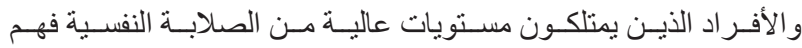

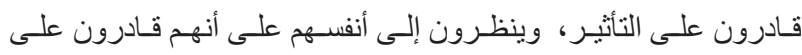
Sinha \&) التأثير في نتيجـة أحداث الحيـاة التي يمكن أن تؤثر عليهـ
يتضـح مـن النتائج وجـود علاقـة ارتباطيـة موجبـة دالـة إحصائيـاً (0.05) بيـن الدرجـة الكليـة لمقيـاس الصـلابـة النفسية وبيـن درجـات الأبعـاد التاليـة مـن مقيـاس الاسـتجابات التكيفيـة: (التحليـل المنطقي، التقييـم الايجابـي،

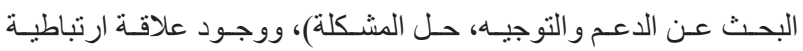
سـالبة دالــة إحصائيـاً (0.05) بيـن الدرجـة الكليـة لمقيـاس الصلابــة

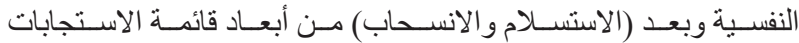

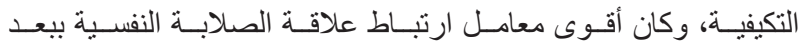

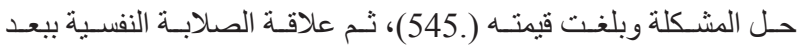
التحليـل المنطقـي وبلغـت قيمتـهـ (325)، ثـم علاقـة الصلابـة النفسـية ببعـد التقييم الايجابـي وبلغت قيمتهـ (325)، ثم علاقـة الصلابـة النفسية ببعـد الاستسـلام و الانسـحاب وبلغت قيمتـه (-.312)، ثم علاقـة الصلابــة

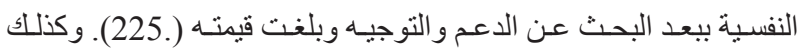
يتضـح مـن نتائسـج الجـدول(3) وجـود علاقـة ارتباطيـة موجبـة دالــة إحصائيـاً (0.05) بيـن درجـات أبعـاد مقيـاس الصلابـة النفسـية الثـلاث وبيـن درجـات الأبعـاد التاليـة مـن قائمــة الاسـتجابات التكيفيـة: (التحليـل

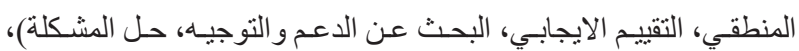

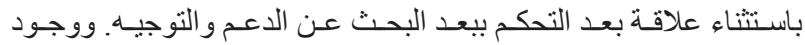

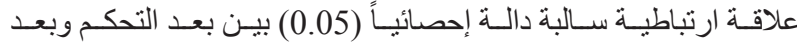

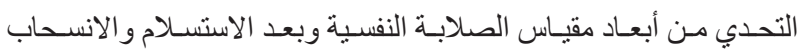

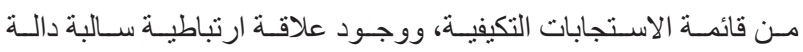

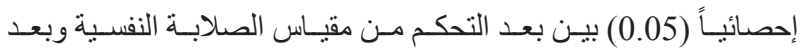
التنفيس العاطفي مـن قائهـة الاسـتجابات التكيفيـة، وكان أقـوى معامـل ارتبـاط علاقـة بعـد الالتـز ام ببعد حل المشكلة وبلغت قيمتهـه (485)، ثم 
2009, (Singh, لذلك نجدهم يوظفون اسـتجابات تكيفيـة تتناسـب وطبيعـة الضغـوط في الغالب تأخذ شكل المو اجهـة و التعامـل حسب متطلبـات الموقف. وقد اتفقت نتيجـة الدر اسـة الحاليـة هـع نتيجـة در اسـة العبدلـي (2012) التـي أظهرت وجـود علاقـة ارتباطيـة ذات دلالـة بيـن غالبيـة أسـاليب مو اجهـة

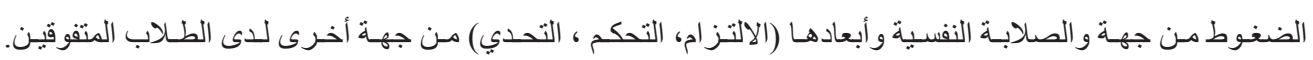

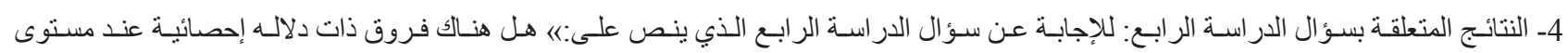

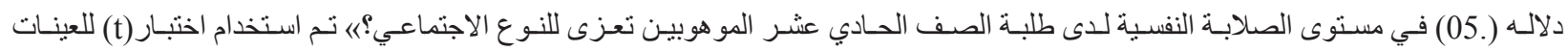

المستقلة كمـا هـو موضـح بالجدول (4):

جدول 4. نتائج اختبار (t) للعينات المستقلة للفروق في مستوى الصلابة النفسية لاى طلبة الصف الحادي عشر الموهوبين باختلاف النوع الاجتماعي

\begin{tabular}{|c|c|c|c|c|c|c|}
\hline \multirow[b]{2}{*}{ مستوى الدلالة } & \multirow{2}{*}{ قيمة } & \multicolumn{2}{|c|}{ أنثى } & \multicolumn{2}{|c|}{ ذكر } & \multirow[b]{2}{*}{ البعد } \\
\hline & & الانحر اف المعياري & المتوسط الحسابي & اللمعيَري اف & المتوسط الحسابي & \\
\hline .031 & -2.19 & 7.37 & 83.62 & 9.56 & 80.12 & الالتز ام \\
\hline .606 & -0.52 & 8.09 & 78.15 & 9.27 & 77.29 & التحكم \\
\hline .019 & -2.38 & 8.48 & 79.77 & 10.27 & 75.54 & التحدي \\
\hline .037 & -2.11 & 6.15 & 80.56 & 8.43 & 77.66 & الدرجة الكلية \\
\hline
\end{tabular}

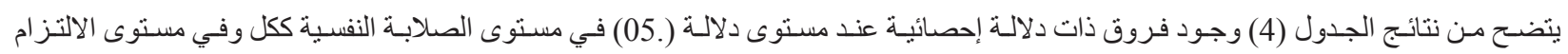

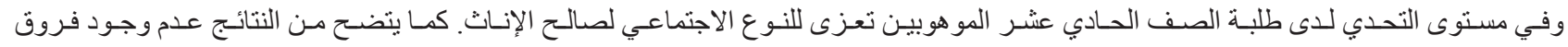

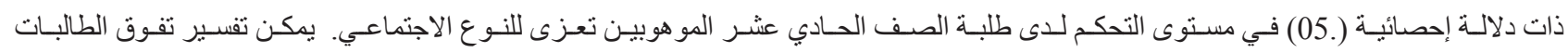

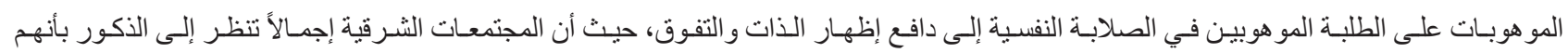

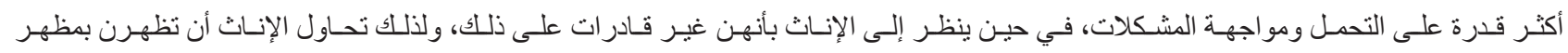

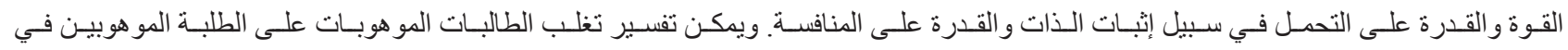

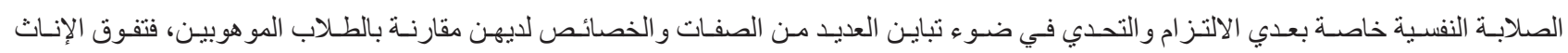

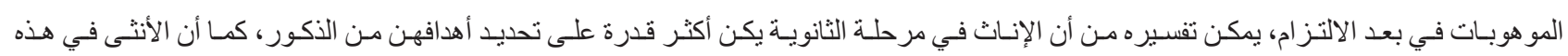

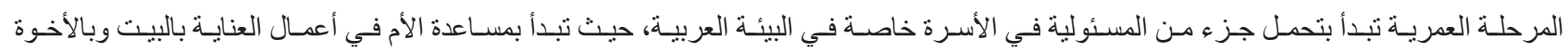

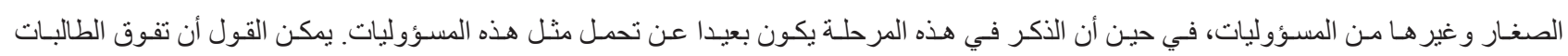

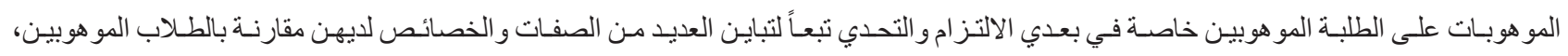
حيـ أظهـرت نتائج الدر اسـات ومنهـا در اسـة (Keer, 1997) أن الإنـاث تفوقن على الذكور في الأعمـال التـي تتطلب التحدي و الدقـة وإيجـاد التفاصيل و التعرف على الاختلافـات الدقيقة (السـليمان، 2008). و أظهرت نتائج در اســة صـادق (2010) إلـى وجـود فرق دال إحصـائيـا بيـن الطـلاب المو هو بيـن

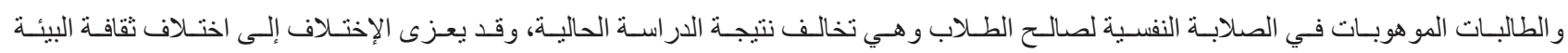
المصريـة عـن بيئة الطلبـة المو هوبيـن في الدر اسـة الحاليـة.

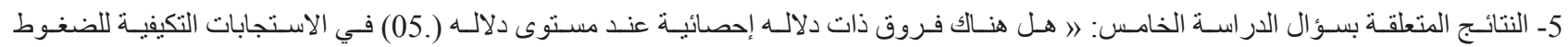

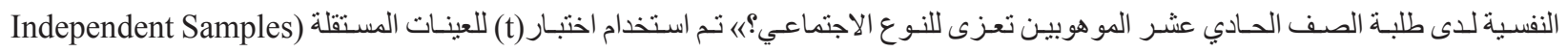

(5_t_Test

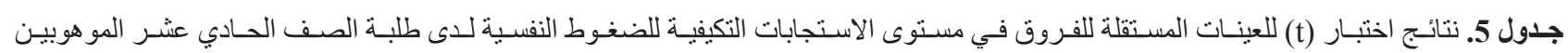
باختلاف النوع الاجتماعي

\begin{tabular}{|c|c|c|c|c|c|c|}
\hline \multirow[b]{2}{*}{ مستوى الدلالة } & \multirow{2}{*}{ قيمة } & \multicolumn{2}{|c|}{ أنثى } & \multicolumn{2}{|c|}{ ذكر } & \multirow[b]{2}{*}{ 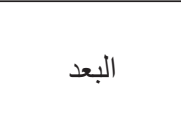 } \\
\hline & & الإنحيرّافي & المتوسط الحسابي & الانحر اف المعياري & المتوسط الحسابي & \\
\hline 063. & -1.88 & 12.53 & 76.35 & 13.87 & 71.62 & التحليل المنطقي \\
\hline 028. & -2.23 & 15.17 & 67.68 & 17.56 & 60.63 & التقييم الايجابي \\
\hline 022 . & -2.32 & 21.14 & 50.67 & 23.52 & 40.82 & البحث عن اللوجيه \\
\hline
\end{tabular}




\begin{tabular}{|c|c|c|c|c|c|c|}
\hline 104. & -1.64 & 18.83 & 69.70 & 20.71 & 63.53 & حل المشكلة \\
\hline 451. & -0.76 & 18.98 & 52.53 & 17.07 & 49.88 & التجنب المعرفي \\
\hline 805. & 0.25 & 18.79 & 48.23 & 20.18 & 49.15 & الاستسلام و الانسحاب \\
\hline 719. & -0.36 & 18.31 & 54.21 & 19.69 & 52.90 & البحث عن حلول بديلة \\
\hline 029. & -2.22 & 19.55 & 46.29 & 22.45 & 37.44 & التنفيس العاطفي \\
\hline
\end{tabular}

تبعـا للنوع الاجتماعي. فالقالب النمطي للعاطفة يظهر للأنثى على أنها

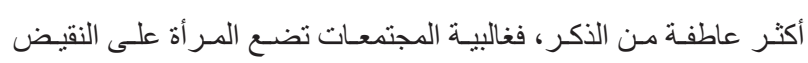

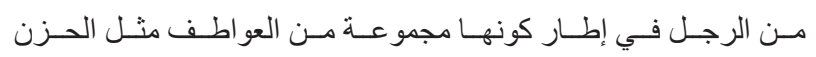

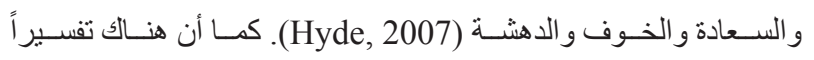
محتمـلاً لاسـتخدام الإنـاث التفيس العاطفي أكثر مـن الذكور هـو هرمـون

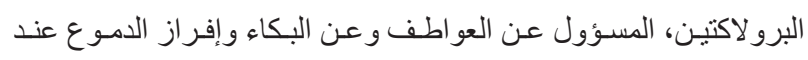

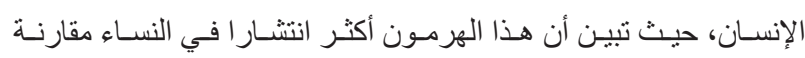

بالرجـال (Wilson, 2008).

وفي هـذا السـياق توصلـت دراسـة (عربيـات و الخر ابثــة، 2007) إلـى عـدم وجـود فـروق دالــة إحصائيـاً فـي اسـتـذام إســر اتيجيات

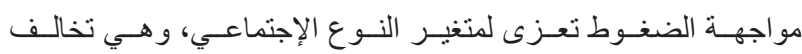

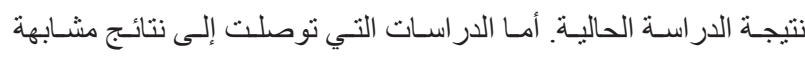

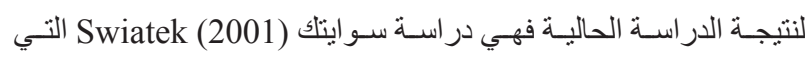

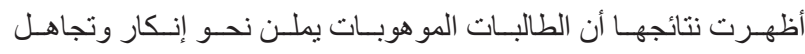

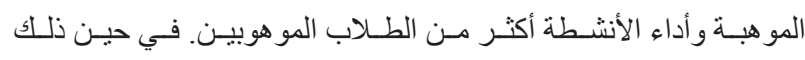

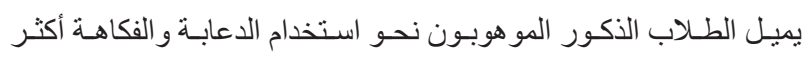

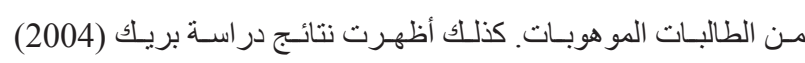
أن الإنــاث كـن أكثـر ميـلاً لإنــكار الموهبـة مقارنــة بالذكـور . ويمكـن تفسـير سـبب الاختـلاف بالنسـبة لدر اســة (عربيـات و الخر ابثــة، 2007)

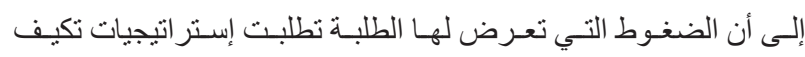

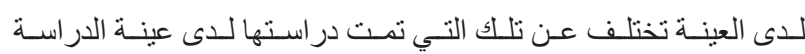

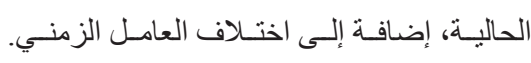

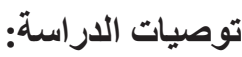

في ضـو ع مـا توصلـت إليـه الدر اسـة الحاليـة مـن نتائسج، وفي ضـوء

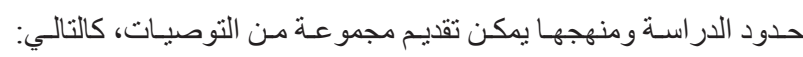

1- الاهتمـام بالبر امــج التدريبيـة الإرشـادية التـي تعدـل علـى تنميــة

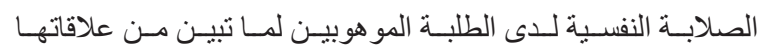
الايجابيـة مـع قـدرة الموهوبيـن على توظيـف الاسـتجابات التكيفيـة للضغــوط النفــية الإيجابيـة فـي حياتهـم اليوميـة.

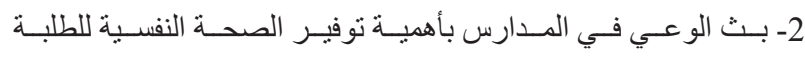

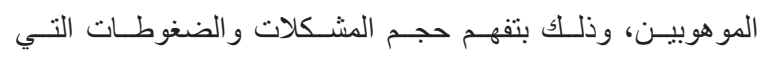
يتعرضــون لهـا و المســاهمة فـي التقليـل مـن حـدة الضغوطـات و المواقـف الصعبــة.
يتضــح مـن نتائسج الجـدول (5) وجـود فـروق ذات دلالــة إحصائيـة

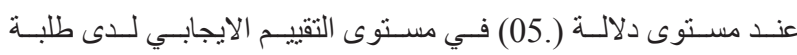

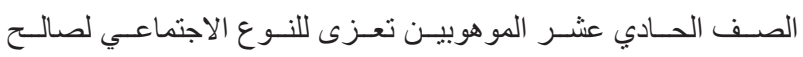
الإنـاث بمتوسط حسـبي (67.68) لدرجـات الإنـاث و (60.63) لدرجـات الذكور، ووجـود فـروق ذات دلالـة إحصـائيـة (05) في مسـتوى البحـث

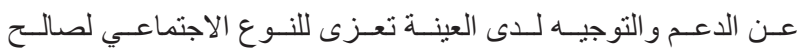
الإنـاث بمتوسط حسـبي (50.67) لدرجـات الإنـاث و(40.82) لارجـات

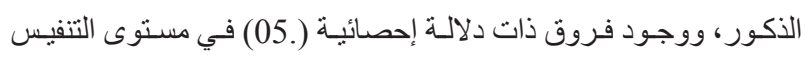
العاطفي لـدى العينـة تعزى للنـوع الاجتماعـي لصالـح الإنـاث بمتوسط حسـابي (46.29) لدرجـات الإنـاث و (37.44) لدرجـات الذكـور . كــا يتضـح مـن نتائج الجدول (18) عدم وجـود فروق ذات دلالـة إحصائيـة

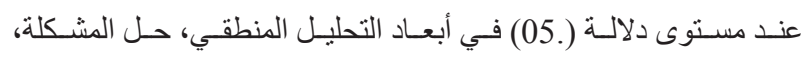
التجنـب المعرفـي، الاستســلام و الانسـحاب، البحــث عـن حلـول بديلــة

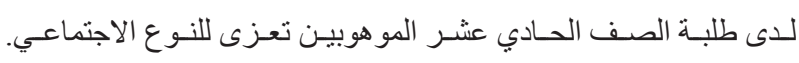
يمكن تفسـير تفـوق الطالبـات المو هوبـات على الطلبـة المو هوبيـن في القدرة على التقيبـم الايجابسي و القدرة على البحـث عن الدعم و التوجيـهـ مـن خصائـص الموهوبـات، فهـن أكثـر تفوقـاً مـن الذكـور فـي القـدرة

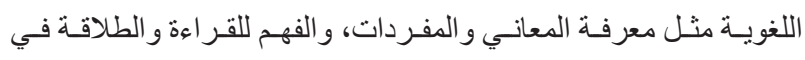
التعبيـر و الطلاقـة في فهم المعانـي للكلمـات، وهـذا يجعلهـن أكتر قدرة مـن الذكور على البحث عـن مصسادر الدعم و التوجيـه و التو اصـل معهـا

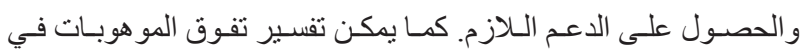
القدرة على التقييـم الايجابـي مـن حيـث أن المو هوبـات الإنـاث يتفوقـن على المو هو بيـن الذكور في الأعمـال التي تتطلب الدقـة و إيجـاد التفاصيل و التعـرف على الاختلافـات الدقيقة، مدـا يرفـع مـن قدرنهـن على تقييـم المو اقـف المختلفـة (السـليمان، 2008). ويمكـن تفسـير تفـوق الطالبـات

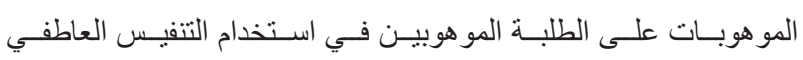
كاستجابة تكيفيـة مـع الضغوط النفسية مـن حيـث أن الإنـاث يغلب عليهن

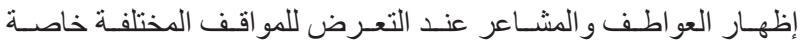
الضـاغطـة منهـا، خاصـة فـي المجتمعـات العربيـة حيـث يعتبـر التنفيس

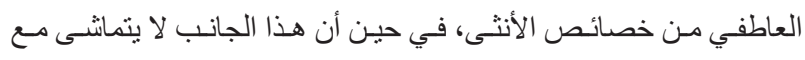
صفـات الذكور في المجتمع العربـي، فالطالب في المرحلـة الثانويـة يبـدأ

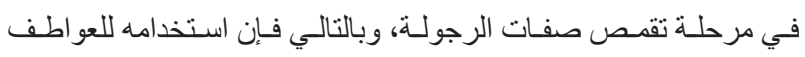
و المشــاعر في مو اجهة المو اقف الضـاغطـة يتعـارض مـع صفاتـه كرجل.

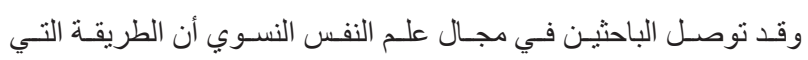

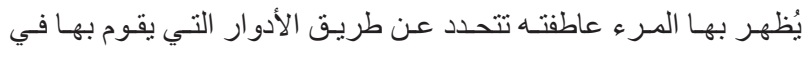

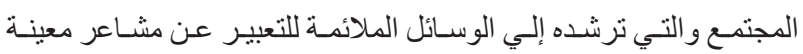


مو اجهـة الضغـوط النفسـية لـدى عينــة مـن طـلاب المرحلـة الثانويـة المتفوقيـن در اسـياً و العادييـن بمكـة المكرمــة (رسـالة ماجستنير غيـر منشـورة). جامعـة أم القرى، المملكـة العربيـة السـودية.

القرنـي، علـي بـن عبدالخالـق. (2012، يوليـو). الموهبـة و المو هوبـون.

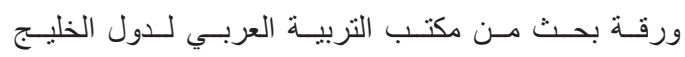

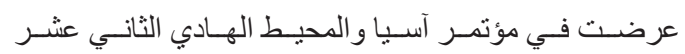
للمو هبـة، دبـي، الإمــار ات العربيـة المتحـدة.

المطيـري، ثامـر. (2005). التغيـر فـي الثـعور بحـدة المشـكلات

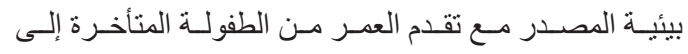
المر اهقة: در اسـة مقارنــة بيـن المو هوبيـن و العادييـن (رسـالة ماجسـتير غيـر منشــورة). جامعـة الخليـجـ العربـي، البحريـن.

بطـرس، حافظظ بطرس. (2013). المشـكلات النفسـية وعلاجهـا (ط3). عمـان: دار المسـيرة للنشـر و التوزيـع.

جـروان، فتحـي عبدالرحمـن. (2013). أسـاليب الكثـف عـن المو هوبيـن

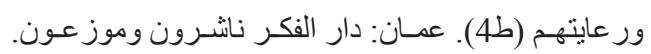

جـروان، فتحـي عبدالرحمـن. (2015). المو هبــة والتفوق (ط6). عمـان: دار الفكـر ناشـرون وموزعـون.

دخـان، نبيـل و الحجــار، بشـير. (2007). الضغــوط النفسـية لـدى طلبــة

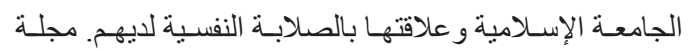
الجامعـة الإســلامية، 14(2)، 369-389.

صـادق، ياسـر صـادق. (2010). بعـض المتغيـر ات النفسـية المنبئـة

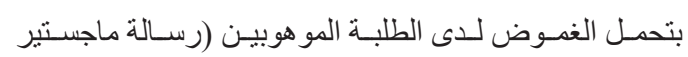

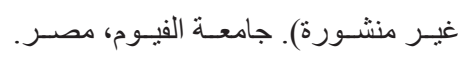

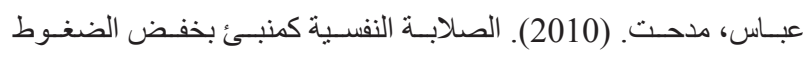
النفسـية و السـلوك كالعدو انسي لـدى معلمـي المرحلــة الإعداديـة.

مجلــة كليـة التربيـة، 26 (1)، 168-233.

عبدالـرؤوف، فتحبـة. (1999). اختبـار المصفوفـات المتتابعـة: كر اســة

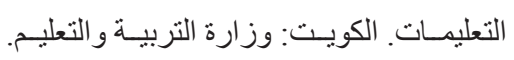

عبيـد، ماجـدة بهـاء الديـن السـيد (2008). الضغــط النفسـي ومشـكلاته

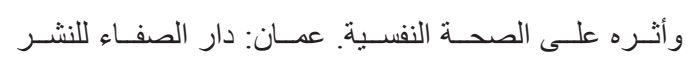

$$
\text { و التوزيـع. }
$$

عسـكر، علـي. (2003). ضغــوط الحيـاة و أسـاليب مو اجهتهـا: الصحـة

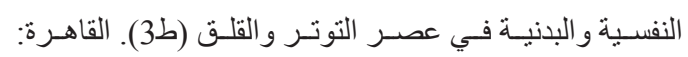

$$
\text { دار الكتـاب الحديـث. }
$$

عـودة، محمــد محمـــ (2010). الخبـرة الصـادمــة وعلاقتهــا بأسـاليب

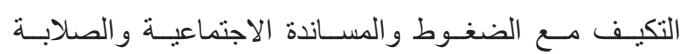

\section{المراجع العربية}

أبـو أسـعد، أحمـــ عبداللطيـف. (2014). إرشـاد الموهوبيـن و المتفوقيـن (2). عمـان: دار المسـيرة للنشـر و التوزيـع.

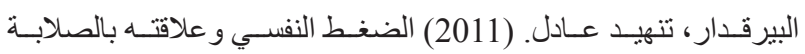
النفسية لـدى طلبـة كليـة التربيـة. مجلـة أبحـاث كليـة التربيـة

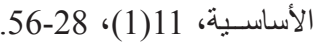

الحربـي، خلــف. (2002). المشـكلات الانفعاليـة والاجتماعيـة للطلبـة المتميزيـن الملتحقيـن فـي البرامـج الخاصــة وغيـر الملتحقيـن

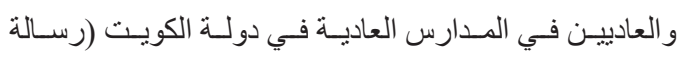
ماجسـتير غيـر منشـورة). جامعـة الخليـج العربـي، البحريـن. الحربـي، خلف. (2011). المشكلات الانفعاليـة والاجتماعيـة للمو هوبيـن و المتميزيـن. الكويـت: دار المسيلة للنشـر و التوزيـع.

الجهني، عبدالرحمن. (2011). المهار ات الاجتماعيـة و علاقتها بالسـلوك

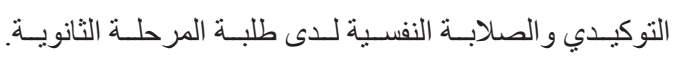
مجلـة جامعـة أم القـرى للعلــوم الاجتماعيـة، 4(1)، 193-238. الدلمانـي، ماجـد مسـيجهيج. (2007). المشـكلات السـلوكية للطـلاب

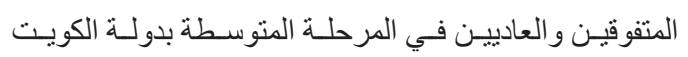

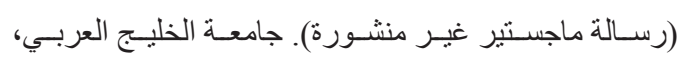
البحريسن.

السـرور، ناديـا هايـلـ. (2010). مدخـل إلـى تربيـة المتميزيـن و المو هو بيـن (5). عمـان: دار الفكر ناشـرون وموزعون.

السـليمان، نــورة إبر اهـــ. (2008). بعـض الفـروق بيـن الجنسـين فـي

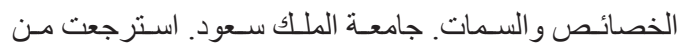

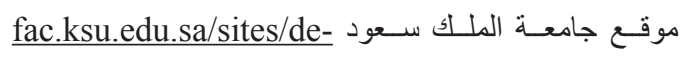
fault/.../lfrwq_byn_ljnsyn_fy_lmwhb_wltfwq. .doc الســـادوني، السـبـد إبر اهيـــ. (2014). تربيــة الموهوبيـن و المتفوقيـن. عمسان: دار المسـيرة. الثــواف، غـادة علـي. (2010). الصلابــة النفسـية كمتغيـر معـدل

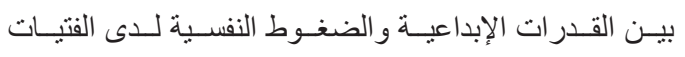

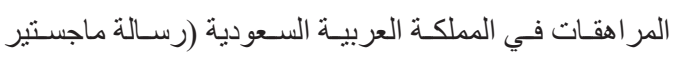
غيـر منشـورة). جامعـة الخليـجـ العربـي، البحريـن. الضريبي، عبدالله. (2010). أسـاليب مو اجهـة الضغـوط النفسية المهنيـة

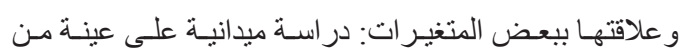

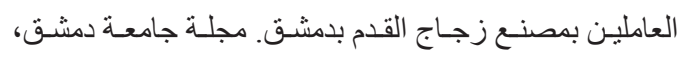

$.719-669$ ،(4)26

العبدلي، خالـد بـن محمد. (2012). الصلابـة النفسية و علاقتهـا بأسـاليب 
tion", Florence, Italy.

Clark, B. (2002). Growing up gifted: Developing the Potential of Children at Home and School $\left(6^{\text {the }}\right.$ ). USA: Merrill Prentice Hall.

Cohen, R. (2005). Psychology \& Adsjustment, values, culture and changes. USA: Bosten Allyn and Bacon.

Cross, T. L., \& Swiatek, M. A. (2009). Social coping among academically gifted adolescents in a residential setting: A longitudinal study. Gifted Child Quarterly,53(1), 25-33.

Crowely, B., Hayslip, B. \&Haddy, J. (2003). Psychological hardiness and adjustment to life events in adulthood. Journal of adult development, 10(4), $237-248$.

Harvatin, H. C. (2009). Hardiness and coping Strategies (master's thesis). Available from ProQuest Dissertations and Thesis database. (UMI No.1460659)

Hutcheson, V. H., \& Tieso, C. L. (2014). Social Coping of Gifted and LGBTQ Adolescents. Journal for the Education of the Gifted, 37(4), 355-377.

Hyde, J. S. (2007). Half the human experience: The psychology of women (7th ed.). Boston MA: Houghton Mifflin Company.

Kobasa, S. C. (1979). Stressful life events, personality and health: An inquiry into hardiness. Journal of personality and social psychology, 37(1), 1-11.

Kobasa, S. C. (1982). Commitment and coping in stress resistance among lawyers. Journal of personality and social psyology, 42(4), 707-717.

Kobasa, S. C., Maddi, S. R., \& Kahn, S. (1982). Hardiness and health: a prospective study. Journal of personality and social psychology, 42(1), 168.

Kobasa, S. \&Puccetti, M. (1983). Personality and social resources in stress resistance. Journal of personality and social psychology, 45(4), 839-850.

Kobasa, S. C., Maddi, S. R., Puccetti, M. C., \& Zola, M. A. (1985). "Effectiveness of hardiness, exercise and social support as resources against illness". Journal of Psychosomatic Research, 29 (5).

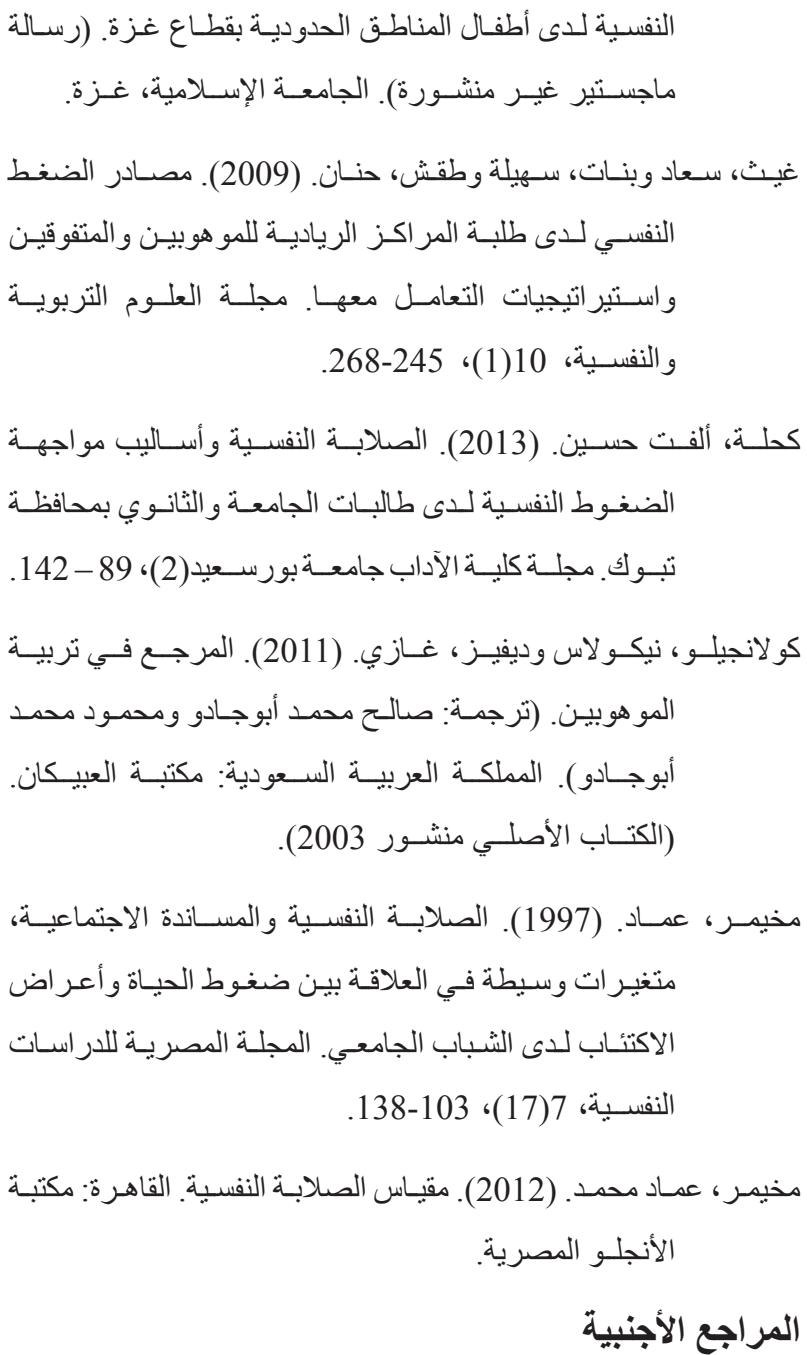

Aldao, A., \& Nolen-Hoeksema, S. (2010). Specificity of cognitive emotion regulation strategies: A transdiagnostic examination. Behaviour research and therapy, 48 (10), 974-983.

Bainbridge, C. (2014). Social and Emotional Problems Affecting Gifted Children, from: http://giftedkids.about.com/od/socialemotionalissues/a/gtproblems.htm.

Barber-Marsh, K. A. (2007). An exploration of gifted and highly able adolescents' experiences with stress and coping (master Dissertation, Brock University). Retrieved https://dr.library.brocku.ca/handle/10464/1664.

Chan, D. W. (2009). Perfectionism and goal orientation among Chinese gifted students in Hong Kong. Roeper Review, 31(1), 9-17.

Chemi, T. (2012, June). The Future of Artistic Creativity: Models of Integration in School Curriculum. International Conference "The future of Educa- 
ences in gifted middle school students. Roeper Review, 23(1), 39-44.

Sinha V. \& Singh R. N. (2009). Immunological Role of Hardiness on Depression. Indian Journal of Psychological Medicine, 31(1), 39-44.

Skirka, N. (2000). The relationship of hardiness, sense of coherence, sports participation, and gender to perceived stress and psychological symptoms among college students. Journal of Sports Medicine and Physical Fitness, 40(1) , 6370 -.

Stasiowski, S. (2008). Optimism and Hardiness: Influence on Coping and Psychological Distress (Doctoral dissertation). Available from ProQuest dissertation and Thesis database. (UMI No. 3311534)

Swaitek, M. (2001). Social coping among gifted high school student and its relationship to self-concept. Journal of youth and adolescence, 30(1), 19-39.

Sayiner, B. (2006). Stress level of university students. Istanbul University Journal of Science, 5 (10), 23-34.

Torrance, P. (2008). Torrance Tests of Creative Thinking to be used in conjunction with the norms-technical manual. USA: Scholastic Testing Service.

VanTassel-Baska, J. (2009). Leading change in gifted education. Texas: PruFrock Press Inc.

Wilson, T. V. (2008). How Women Work: Women and Emotions: Retrieved from: http://people.howstuffworks.com/women2.htm/printable.

Yang, Y. (2012). The interaction effects on academic stress of gifted student and normal student by academic self-efficacy and stress coping styles. Journal of Gifted/Talented Education, 22(4), 841-853
$525-533$.

Krohne, H. W. (2002). Stress and coping theories. The international encyclopedia of the social and behavioral sciences, 22, 15163-15170.

Lazarus, R. S. (2003). Psychological Stress and Emotional: Ahistory of changing outlooks. New York: John Wiley\& Sons, Inc.

Maddi, S., Khan, S. \& Maddi, K. (1998). The effectiveness of hardiness training. Consulting Psychology Journal Practice and Research, 50(2), 78-86.

Malin, J., \& Matthwe, C. M. (2012). Ghender differences in gifted students advice on solving the worlds problems. Journal for the Education of Gifted, $35,175-187$.

McLeod, S. A. (2010). Coping with stress is the process by which a person consciously attempts to master, minimize, or tolerate stressors and problems in life. Retrieved from https://www.boundless. com/psychology/textbooks/boundless-psychology-textbook/stress-and-health-psychology-17/ improving-habits-and-managing-stress-89/coping-with-stress-337-12872/.

Morrisy, C. \& Hanna, T. (2001). Measurement of psychological hardiness in adolescent. Journal of genetic psychology, 184(3), 393-397.

Moss, R. (2004). Coping responses inventory. USA: P.A.R Psychological Assessment Resources, Inc.

Preuss, L. J., \& Dubow, E. F. (2004). A comparison between intellectually gifted and typical children in their coping responses to a school and a peer stressor. Roeper Review, 26(2), 105-111.

Renzulli, J. \& Reis, S. (2003). Conception of giftedness and its relationship to the development of social capital. In N. Colangelo \& G. Davis (Eds.), Handbook of gifted education $\left(3^{\text {rd }}\right.$ ed.; pp 7587). Boston: Ally \& Bacon.

Seawared, B. (1999). Managaing stress, principles and strategies for health and wellbeing. Bosten: Jons \& Bartltt publishers.

Siegle, D. \&Patricia, A. S. (2000). Perfectionism differ- 
